\title{
Evaluating the impact of maternal vitamin D supplementation: I. Sow performance, serum vitamin metabolites, and neonatal muscle characteristics ${ }^{1,2}$
}

\author{
J. R. Flohr,*3 J. C. Woodworth,* J. R. Bergstrom, $\dagger$ \\ M. D. Tokach, * S. S. Dritz, R. D. Goodband, $* 4$ and J. M. DeRouchey* \\ *Department of Animal Sciences and Industry, College of Agriculture, Kansas State \\ University, Manhattan 66506-0201; †DSM Nutritional Products, Parsippany, NJ 07054; and †Department \\ of Diagnostic Medicine/Pathobiology, College of Veterinary Medicine, Kansas State University, Manhattan 66506-0201
}

\begin{abstract}
In Exp. 1, 56 gestating sows (PIC $1050 ; 35 \mathrm{~d}$ postinsemination) were used in a 30 -d trial to determine serum $25(\mathrm{OH}) \mathrm{D}_{3}$ response to increasing concentrations of dietary vitamin $\mathrm{D}_{3}$. Sows were randomly allotted to 1 of 7 dietary $\mathrm{D}_{3}$ treatments $(200,800,1,600,3,200,6,400,12,800$, or $25,600 \mathrm{IU}$ of added $\mathrm{D}_{3}$ per kilogram of complete diet) with 8 sows per treatment. Increasing $\mathrm{D}_{3}$ increased (quadratic; $P<0.001)$ serum $25(\mathrm{OH}) \mathrm{D}_{3}$ with the response depicted by the prediction equation: serum $25(\mathrm{OH})$ $\mathrm{D}_{3}, \mathrm{ng} / \mathrm{mL}=35.1746+\left(0.002353 \times\right.$ dietary $\mathrm{D}_{3}$, $\mathrm{IU} / \mathrm{d})-\left(0.0000000156 \times\right.$ dietary $\left.\mathrm{D}_{3}, \mathrm{IU} / \mathrm{d}^{2}\right)$. In Exp. 2, 112 sows and their litters were used to determine the effects of dietary vitamin $\mathrm{D}$ regimen on sow performance, subsequent preweaning pig performance, neonatal bone and muscle characteristics, and serum vitamin metabolites. Sows were allotted to 1 of 4 dietary treatments 3 to $5 \mathrm{~d}$ following breeding: 800, 2,000 , or $9,600 \mathrm{IU}$ of $\mathrm{D}_{3}$ per kilogram of the diet or $50 \mu \mathrm{g}$ of $25(\mathrm{OH}) \mathrm{D}_{3}\left(2,000 \mathrm{IU}\right.$ of $\mathrm{D}_{3}$ equivalent from Hy-D, DSM Nutritional Products, Parsippany, NJ) per kilogram of diet. There were 25 to 27 sows per treatment. Increasing dietary $\mathrm{D}_{3}$ increased (linear, $P$ $=0.001)$ serum $25(\mathrm{OH}) \mathrm{D}_{3}$ of sows on $\mathrm{d} 100$ of gestation, at farrowing, and at weaning. Increasing $\mathrm{D}_{3}$ in
\end{abstract}

sow diets increased piglet serum $25(\mathrm{OH}) \mathrm{D}_{3}$ at birth (linear, $P=0.001$ ) and weaning (quadratic, $P=0.033$ ). Sows fed $50 \mu \mathrm{g}$ of $25(\mathrm{OH}) \mathrm{D}_{3} / \mathrm{kg}$ had intermediate $(P<0.004)$ serum $25(\mathrm{OH}) \mathrm{D}_{3}$ concentrations on $\mathrm{d} 100$ of gestation, at farrowing, and at weaning compared with sows fed 2,000 IU of $\mathrm{D}_{3} / \mathrm{kg}$ and sows fed 9,600 $\mathrm{IU}$ of $\mathrm{D}_{3} / \mathrm{kg}$. Pigs from sows fed $50 \mu \mathrm{g}$ of $25(\mathrm{OH}) \mathrm{D}_{3} /$ $\mathrm{kg}$ had greater serum $25(\mathrm{OH}) \mathrm{D}_{3}$ compared with pigs from sows fed $2,000 \mathrm{IU}$ of $\mathrm{D}_{3} / \mathrm{kg}$, but at weaning, serum $25(\mathrm{OH}) \mathrm{D}_{3}$ concentrations were similar. Also, pigs from sows fed 9,600 IU of $\mathrm{D}_{3} / \mathrm{kg}$ had greater $(P=0.011)$ serum $25(\mathrm{OH}) \mathrm{D}_{3}$ at birth and weaning compared with pigs from sows fed $50 \mu \mathrm{g}$ of $25(\mathrm{OH})$ $\mathrm{D}_{3} / \mathrm{kg}$. Maternal performance, litter characteristics, neonatal bone ash content, and neonatal muscle fiber characteristics were largely unaffected by the dietary vitamin D treatments. Overall, $\mathrm{D}_{3}$ and $25(\mathrm{OH}) \mathrm{D}_{3}$ are both useful at increasing serum $25(\mathrm{OH}) \mathrm{D}_{3}$ concentrations, but more $\mathrm{D}_{3}$ (on an equivalent IU basis) is needed to achieve similar serum $25(\mathrm{OH}) \mathrm{D}_{3}$ responses compared with feeding $25(\mathrm{OH}) \mathrm{D}_{3}$. Concentration of maternal vitamin $\mathrm{D}$ supplementation in lactation impacted milk transfer of the vitamin more so than the form of the vitamin, as evidence by the weaned pig serum $25(\mathrm{OH}) \mathrm{D}_{3}$ concentrations.

Key words: $25(\mathrm{OH}) \mathrm{D}_{3}$, sow nutrition, vitamin $\mathrm{D}$, muscle characteristics

(C) 2016 American Society of Animal Science. All rights reserved.

J. Anim. Sci. 2016.94:4629-4642
doi:10.2527/jas2016-0409

\section{INTRODUCTION}

\footnotetext{
${ }^{1}$ Contribution number 16-228-J from the Kansas Agricultural Experiment Station, Manhattan, KS.

${ }^{2}$ The authors wish to thank DSM Nutritional Products, Parsippany, NJ, for partial financial support.

${ }^{3}$ Present address: Nutriquest, LLC, Mason City, IA 50401.

${ }^{4}$ Corresponding author: goodband@ksu.edu

Received February 23, 2016.

Accepted August 20, 2016.
}

The most common form of dietary vitamin D supplemented in livestock diets is cholecalciferol (vitamin $\mathrm{D}_{3}$ ). Research examining a synthetically produced 25(OH) $\mathrm{D}_{3}$ (Hy-D, DSM Nutritional Products North America, Parsippany, NJ) has shown increased serum $25(\mathrm{OH}) \mathrm{D}_{3}$ compared with vitamin $\mathrm{D}_{3}$ when 
both vitamin $\mathrm{D}_{3}$ and $25(\mathrm{OH}) \mathrm{D}_{3}$ were added in diets at 2,000 IU of vitamin D (Lauridsen et al., 2010). This is because the vitamin $\mathrm{D}$ binding protein (chaperone protein for vitamin $\mathrm{D}$ metabolites in circulation) has a higher affinity for $25(\mathrm{OH}) \mathrm{D}_{3}$ compared with vitamin $\mathrm{D}_{3}$ (Bouillon et al., 1980).

Research examining the role of vitamin D in skeletal muscle development concluded that vitamin D is involved in myogenic signaling pathways, and the in utero alterations were evident in postnatal skeletal muscle growth (Endo et al., 2003). A study in gestating gilts concluded that when adding either 2,500 IU of vitamin $\mathrm{D}_{3}$ or $500 \mathrm{IU}$ of vitamin $\mathrm{D}_{3}$ and $50 \mu \mathrm{g}$ of $25(\mathrm{OH}) \mathrm{D}_{3}$ in the diet (both treatments having similar IU equivalency), maternal and fetal serum $25(\mathrm{OH}) \mathrm{D}_{3}$ were increased with added dietary $25(\mathrm{OH}) \mathrm{D}_{3}$ (Coffey et al., 2012). Additionally, the authors concluded that reproductive performance of gilts was improved with $25(\mathrm{OH}) \mathrm{D}_{3}$ supplementation. Interestingly, Hines et al. (2013) found alterations in fetal muscle characteristics in fetuses from gilts fed $25(\mathrm{OH})$ $\mathrm{D}_{3}$ when compared with fetuses from gilts fed vitamin $\mathrm{D}_{3}$. If these changes in fetal muscle development lead to improvements in postnatal performance, they will increase profitability of swine producers.

Therefore, the objectives were 1) to determine a feeding level of vitamin $\mathrm{D}_{3}$ that would result in a serum $25(\mathrm{OH}) \mathrm{D}_{3}$ response similar to that observed from feeding $50 \mu \mathrm{g} / \mathrm{kg}$ of $25(\mathrm{OH}) \mathrm{D}_{3}$ in gestating sows and 2) to evaluate the effects of vitamin $D_{3}$ (above the basal requirement level) or the supplementation with $50 \mu \mathrm{g} / \mathrm{kg}$ of $25(\mathrm{OH}) \mathrm{D}_{3}$ on sow performance, serum vitamin metabolites, subsequent pig performance, and neonatal muscle and bone characteristics.

\section{MATERIALS AND METHODS}

\section{General Description}

The Kansas State University Institutional Animal Care and Use Committee approved the protocol used in this experiment. These experiments were conducted at the K-State Swine Teaching and Research Facility in Manhattan, KS, and were conducted from January through December of 2014. Both the gestation and farrowing barns were totally enclosed, environmentally controlled, and mechanically ventilated buildings. In gestation, sows were housed in gestation stalls $(2.1 \times$ $0.6 \mathrm{~m})$. The farrowing barn contained 29 farrowing crates $(2.1 \times 0.6 \mathrm{~m}$ for the sow and $2.1 \times 1.0 \mathrm{~m}$ for the pigs) that were each equipped with a single feeder and nipple waterer. Temperature in the farrowing house was maintained at a minimum of $21^{\circ} \mathrm{C}$, and supplemental heat was provided to piglets with heat lamps. Gestation and lactation sow diets were prepared at the Kansas State University O. H. Kruse Feed Mill (Manhattan, KS). All diets were formulated to meet or exceed nutrient requirement estimates (NRC, 2012).

\section{Animals, Diets, and Treatment Design}

In Exp. 1, a total of 56 sows (PIC 1050) from 2 consecutive breeding groups were used in a $30-\mathrm{d}$ study to determine the serum $25(\mathrm{OH}) \mathrm{D}_{3}$ response to varying concentrations of dietary vitamin $\mathrm{D}_{3}$. The study began $35 \mathrm{~d}$ postinsemination and after sows were confirmed pregnant. At initiation, the sows were randomly allotted to 1 of 7 dietary treatments receiving 200, 800, 1,600, 3,200, $6,400,12,800$, or $25,600 \mathrm{IU}$ vitamin $\mathrm{D}_{3} / \mathrm{kg}$ of complete diet. There were 8 sows per treatment. The gestation diets were common corn-soybean meal-based diets formulated to contain $0.56 \%$ standardized ileal digestible (SID) Lys and $0.82 \% \mathrm{Ca}$ (Table 1 ). All sows were fed once daily (at $0800 \mathrm{~h}$ ) and received $2.5 \mathrm{~kg}$ of feed. Prior to receiving their daily meal, sows were bled on $\mathrm{d} 0$ and 30 of the trial via jugular venipuncture to collect serum for $25(\mathrm{OH}) \mathrm{D}_{3}$ analysis. Results from this study were then used to develop a prediction equation to determine the dietary vitamin $\mathrm{D}_{3}$ concentration needed to achieve a serum $25(\mathrm{OH}) \mathrm{D}_{3}$ response in gestating sows similar to levels previously reported in the literature (Weber et al., 2014) for females fed $50 \mu \mathrm{g}$ of $25(\mathrm{OH}) \mathrm{D}_{3} / \mathrm{kg}$ of complete diet as their sole source of vitamin D.

In Exp. 2, a total of 112 sows (PIC 1050) from 4 consecutive farrowing groups and their litters were used in the study. Following breeding, sows were randomly assigned to 1 of 4 dietary vitamin D treatments receiving $800 \mathrm{IU}, 2,000 \mathrm{IU}$, or 9,600 IU of vitamin $\mathrm{D}_{3} / \mathrm{kg}$ of complete diet or $50 \mu \mathrm{g}$ of $25(\mathrm{OH}) \mathrm{D}_{3} / \mathrm{kg}$ of complete diet. The treatment of $800 \mathrm{IU}$ of vitamin $\mathrm{D}_{3} /$ $\mathrm{kg}$ was selected since it represents the basal requirement of the sow (NRC, 2012). The treatment of 2,000 IU of vitamin $\mathrm{D}_{3} / \mathrm{kg}$ was used to directly compare to feeding $50 \mu \mathrm{g}$ of $25(\mathrm{OH}) \mathrm{D}_{3}$, representing the same IU equivalency. The treatment of 9,600 vitamin $\mathrm{D}_{3} / \mathrm{kg}$ was determined following the results found in Exp. 1 and was predicted to provide mean serum $25(\mathrm{OH}) \mathrm{D}_{3}$ values that would be similar to the treatment fed $50 \mu \mathrm{g}$ of $25(\mathrm{OH}) \mathrm{D}_{3} / \mathrm{kg}$. There were 28 sows per treatment and 6 to 8 replications per farrowing group. During d 0 through 110 of gestation, sows were fed once daily at $0800 \mathrm{~h}$ and received $2.5 \mathrm{~kg} / \mathrm{d}$ of the gestation diets. On d 110, sows were moved to the farrowing house and were housed in farrowing stalls. After farrowing, sows were fed lactation diets. Gestation and lactation diets were formulated to contain $0.56 \%$ and $1.07 \%$ SID Lys, respectively. Farrowing crate feeders were equipped with an electronic feeding system (Gestal Solo; JYGA Technologies, Quebec, Canada) that used a built-in 
feeding curve based on parity to feed individual sows. The feeding curves were monitored and adjusted daily for individual sows to allow for ad libitum feed intake while reducing feed wastage. Lactation feed intake was confirmed by measuring feed disappearance on $\mathrm{d} 7,14$, and 21 (weaning). Sow BW was measured at breeding, d 110 of gestation, within $24 \mathrm{~h}$ of farrowing, and at weaning to determine gestation BW gain and lactation weight loss. Back fat measurements were collected when sows arrived in the farrowing house and at weaning to determine back fat loss. Sows were bled on $\mathrm{d} 0$ and 100 of gestation, within $24 \mathrm{~h}$ after farrowing, and at weaning $(\mathrm{d} 21)$ to determine serum $25(\mathrm{OH}) \mathrm{D}_{3}$, vitamin $\mathrm{D}_{3}$, vitamin $\mathrm{A}$ (retinol), and vitamin $\mathrm{E}$ ( $\alpha$-tocopherol).

Within $24 \mathrm{~h}$ of parturition, all piglets were weighed and ear notched for identification. The male pig closest to the average BW of the litter was euthanized to collect bone and muscle samples for neonatal bone ash content and neonatal muscle immunohistochemistry measurements. The male and female piglets next closest to the average BW of the litter were bled via jugular venipuncture within $24 \mathrm{~h}$ of birth and again at weaning to determine preweaned piglet serum $25(\mathrm{OH}) \mathrm{D}_{3}$, vitamin $\mathrm{D}_{3}$, vitamin $\mathrm{A}$ (retinol), and vitamin $\mathrm{E}$ ( $\alpha$-tocopherol). Mummified and stillborn pigs were recorded to calculate total born. Although minimal, cross-fostering was conducted within vitamin $\mathrm{D}$ dietary treatments within $48 \mathrm{~h}$ after farrowing to help standardize litter size. Pigs were weighed after fostering to measure fostered litter weight. At weaning, piglet weights and piglet counts were recorded to determine individual and litter weight gains, along with survivability.

\section{Feed Preparation and Vitamin D Analysis}

To achieve the dietary vitamin $\mathrm{D}_{3}$ concentrations, a premix was made containing a vitamin $\mathrm{D}_{3}$ supplement (Rovimix $\mathrm{D}_{3}, 500,000 \mathrm{IU} / \mathrm{g}$; DSM Nutritional Products North America). This supplement was mixed into a rice hull carrier to form the premix and was added to the control diet by replacing corn. The vitamin D premix was the only source of added vitamin D within the diets, as other vitamin premixes did not contain vitamin D. For diets formulated to contain $50 \mu \mathrm{g} 25(\mathrm{OH}) \mathrm{D}_{3} / \mathrm{kg}$, $370 \mathrm{~g}$ of $25(\mathrm{OH}) \mathrm{D}_{3}$ (Hy-D, DSM Nutritional Products North America; $125 \mu \mathrm{g} / \mathrm{g}$ of product) were added per ton of the diet to reach desired finished feed concentrations. Complete diet samples from Exp. 1 and 2 were analyzed for vitamin $\mathrm{D}_{3}$ and $25(\mathrm{OH}) \mathrm{D}_{3}$ concentrations by DSM Nutritional Products North America using a combination HPLC and mass spectrometry analytical technique (Schadt et al., 2012).
Table 1. Sow diet composition (as-fed basis) ${ }^{1}$

\begin{tabular}{|c|c|c|}
\hline Item & Gestation $^{2}$ & Lactation \\
\hline \multicolumn{3}{|l|}{ Ingredient, $\%$} \\
\hline Corn & 80.28 & 62.99 \\
\hline Soybean meal, $46.5 \% \mathrm{CP}$ & 15.62 & 30.21 \\
\hline Choice white grease & - & 2.50 \\
\hline Monocalcium phosphate & 1.48 & 1.48 \\
\hline Calcium carbonate & 1.15 & 1.05 \\
\hline Sodium chloride & 0.50 & 0.50 \\
\hline L-Lysine $\mathrm{HCl}$ & - & 0.20 \\
\hline DL-Methionine & - & 0.05 \\
\hline L-Threonine & 0.03 & 0.08 \\
\hline Phytase $^{3}$ & 0.02 & 0.02 \\
\hline Trace mineral premix ${ }^{4}$ & 0.15 & 0.15 \\
\hline Vitamin premix ${ }^{5}$ & 0.75 & 0.75 \\
\hline Vitamin D premix 6 & 0.02 & 0.02 \\
\hline Total & 100.00 & 100.00 \\
\hline \multicolumn{3}{|l|}{ Calculated analysis } \\
\hline \multicolumn{3}{|l|}{ SID AA, ${ }^{7} \%$} \\
\hline Lys & 0.56 & 1.07 \\
\hline Met and Cys:Lys & 76 & 56 \\
\hline Thr:Lys & 80 & 64 \\
\hline Trp:Lys & 24 & 20 \\
\hline $\mathrm{NE}, \mathrm{Mcal} / \mathrm{kg}$ & 2.47 & 2.51 \\
\hline SID Lys:NE, g/Mcal & 2.27 & 4.26 \\
\hline $\mathrm{CP}, \%$ & 14.1 & 19.9 \\
\hline $\mathrm{Ca}, \%$ & 0.82 & 0.83 \\
\hline $\mathrm{P}, \%$ & 0.64 & 0.70 \\
\hline Available P, \% & 0.47 & 0.49 \\
\hline STTD P, $8 \%$ & 0.49 & 0.53 \\
\hline $\mathrm{Ca}: \mathrm{P}$ & 1.28 & 1.19 \\
\hline Vitamin A, IU/kg & 1,102 & 1,102 \\
\hline Vitamin E, IU/kg & 66.1 & 66.1 \\
\hline
\end{tabular}

${ }^{1}$ In Exp. 1, 56 gestating sows were used to determine the serum $25(\mathrm{OH})$ $\mathrm{D}_{3}$ response from feeding titrated concentrations of vitamin $\mathrm{D}_{3}$. In Exp. 2, 112 sows and litters were used to determine the effects of supplemental vitamin $\mathrm{D}$ from varying levels of vitamin $\mathrm{D}_{3}$ or from synthetic $25(\mathrm{OH})$ $\mathrm{D}_{3}$ on maternal performance, subsequent pig performance, sow and piglet $25(\mathrm{OH}) \mathrm{D}_{3}$, neonatal bone mineralization, and piglet muscle development.

${ }^{2}$ Gestation diets for Exp. 1 and 2 were similar in composition.

${ }^{3}$ Ronozyme Hi-Phos, DSM Nutritional Products, Parsippany, NJ. Provided 476 phytase units (FTU/kg) of diet with an expected release of $0.10 \%$ phytate $P$.

${ }^{4}$ Provided $11,000 \mathrm{mg} / \mathrm{kg} \mathrm{Cu}, 198 \mathrm{mg} / \mathrm{kg} \mathrm{I}, 73,413 \mathrm{mg} / \mathrm{kg} \mathrm{Fe}, 22,046$ $\mathrm{mg} / \mathrm{kg} \mathrm{Mn}, 198 \mathrm{mg} / \mathrm{kg} \mathrm{Se}$, and 74,413 mg/kg Zn per kilogram of premix.

${ }^{5}$ Provided 3,527,392 IU vitamin A, 26,455 IU vitamin E, 1,764 mg vitamin $\mathrm{K}, 15 \mathrm{mg}$ vitamin $\mathrm{B}_{12}, 33,069 \mathrm{mg}$ niacin, 11,023 mg pantothenic acid, $3,307 \mathrm{mg}$ riboflavin, $661 \mathrm{mg}$ folic acid, $882 \mathrm{mg}$ pyridoxine, $220,460 \mathrm{mg}$ choline, 19,842 mg carnitine, and $79 \mathrm{mg}$ chromium per kilogram of premix.

${ }^{6}$ Vitamin D premix was mixed to contain 4,409,240 IU of vitamin $\mathrm{D}_{3} / \mathrm{kg}$ of premix by blending vitamin $\mathrm{D}_{3}$ (Rovimix D, DSM Nutritional Products) with rice hulls. Premix replaced a percentage of corn to achieve the desired treatment vitamin $\mathrm{D}_{3}$ concentrations in Exp. 1 and 2. For diets containing $25(\mathrm{OH}) \mathrm{D}_{3}$, the vitamin $\mathrm{D}$ premix was not included, and Hy-D (DSM Nutritional Products; $0.0123 \% 25(\mathrm{OH}) \mathrm{D}_{3}$ ) was added into the diet, replacing a percentage of corn, at $0.37 \mathrm{~kg} / \mathrm{t}$ to achieve the desired concentration of $50 \mu \mathrm{g}$ of $25(\mathrm{OH}) \mathrm{D}_{3} / \mathrm{kg}$ of diet.

${ }^{7} \mathrm{SID}=$ standardized ileal digestible.

${ }^{8}$ Standardized total tract digestible 


\section{Serum 25-Hydroxycholecalciferol, Vitamin $D_{3}$, a-Tocopherol, and Retinol}

All blood samples were collected via jugular venipuncture using 25-mm 20-gauge needles and 10-mL blood collection tubes containing a gel separator. Six hours after collection, blood was centrifuged $(1,600 \times g$ for $25 \mathrm{~min}$ at $2{ }^{\circ} \mathrm{C}$ ), and serum was harvested and stored at $-20^{\circ} \mathrm{C}$ until analysis. All serum $25(\mathrm{OH}) \mathrm{D}_{3}$ testing for Exp. 1 was performed by Heartland Assays Inc. (Ames, IA) using a previously described RIA (Hollis et al., 1993). All vitamin metabolite testing $\left(25(\mathrm{OH}) \mathrm{D}_{3}\right.$, vitamin $\mathrm{D}_{3}$, $\alpha$-tocopherol, and retinol) from Exp. 2 was conducted by DSM Nutritional Product's laboratory (Kaiseraugst, Switzerland). The analyses were performed using a liquid chromatography/electrospray ionization tandem mass spectrometry technique with multiple reaction monitoring similar to the methods described by Priego Capote et al. (2007). The lowest detectable limit was $5.00 \mathrm{ng} / \mathrm{mL}$ for $25(\mathrm{OH}) \mathrm{D}_{3}, 1.00 \mathrm{ng} / \mathrm{mL}$ for vitamin $\mathrm{D}_{3}$, $250 \mathrm{ng} / \mathrm{mL}$ for $\alpha$-tocopherol, and $25 \mathrm{ng} / \mathrm{mL}$ for retinol. Some samples were below the detectable limit for serum vitamin $\mathrm{D}_{3}$ concentration; therefore, the percentage of animals with serum concentrations above the detectable limit is reported herein along with the mean concentration of serum vitamin $\mathrm{D}_{3}$ associated with those animals.

\section{Necropsies, Bone and Tissue Sampling, and Bone Ash Procedure}

Necropsies were performed on site and in compliance with the university's standard operating procedures. Pigs were euthanized using $\mathrm{CO}_{2}$ gas administered via a Euthanex AgPro system (Nutriquest, Mason City, IA). Right femurs and second ribs were collected to determine percentage bone ash, and whole-muscle cross sections of the longissimus thoracis (2-cm section over the fifth and sixth ribs caudal to the trapezius) and the semitendinosus (2-cm section medial to the insertion and origin) were collected for immunohistochemistry. Bones were boiled for $60 \mathrm{~min}$, and adhering tissue was removed. Then the bones were dried at $100^{\circ} \mathrm{C}$ for $7 \mathrm{~d}$. After drying, the bones were ashed in a muffle furnace at $600^{\circ} \mathrm{C}$ for $24 \mathrm{~h}$.

\section{Immunohistochemistry}

After dissecting the whole-muscle cross sections, the cross sections were blotted using blotting paper to measure whole-muscle cross-sectional area. Then the cross sections were embedded in optimal cutting temperature tissue-embedding media (Fisher Scientific, Pittsburgh, $\mathrm{PA}$ ), frozen by submersion in supercooled isopentane, and stored at $-80^{\circ} \mathrm{C}$ until analysis. For each muscle sample, two $10-\mu \mathrm{m}$ cryosections were collected on positively charged slides (MidSci), and muscle fibers were immu- nostained with antibodies validated by Town et al. (2004) for the detection of primary and secondary muscle fibers and merged with the methods of Paulk et al. (2014) to simultaneously identify muscle fiber cross-sectional area. Briefly, nonspecific antigen-binding sites were inhibited by incubating cryosections in 5\% horse serum and $0.2 \%$ TritonX-100 (Fisher Scientific) in PBS for 30 $\mathrm{min}$. All sections were incubated with the following primary antibodies in blocking solution for $60 \mathrm{~min}$ : 1:500 $\alpha$-dystrophin (Thermos Scientific, Waltham, MA), 1:10 supernatant myosin heavy-chain, slow IgG2b (BA-D5, Developmental Studies Hybridoma Bank, University of Iowa, Iowa City, IA), and 1:10 supernatant myosin heavy-chain type 2A, IgG1 (SC-71, Developmental Studies Hybridoma Bank). After incubation, sections were washed with PBS 3 times for $5 \mathrm{~min}$, followed by incubation in the following secondary antibodies $(1: 1,000)$ in blocking solution for $30 \mathrm{~min}$ : Alexa-Fluor 488 goat anti-mouse IgG1 for SC-71 (Invitrogen, San Diego, CA), Alexa-Fluor 633 goat anti-mouse IgG2b for BAD5 (Invitrogen), and Alexa-Fluor 594 goat anti-rabbit H\&L for $\alpha$-dystrophin (Invitrogen). In addition, 1:1,000 Hoechst Dye 33342 (Invitrogen) was utilized to identify all fiber-associated nuclei. Finally, sections were washed for three 5-min periods in PBS and then covered with 5 $\mu \mathrm{L}$ of 9:1 glycerol in PBS and cover slipped for imaging.

Cryosections were imaged using a Nikon Eclipse T1-U inverted microscope with $20 \times$ working distance magnification (Nikon Instruments Inc., Melville, NY). Four representative photomicrographs per section were captured using a Nikon DS-QiMc digital camera (Nikon Instruments Inc.) calibrated to the $20 \times$ objective. For myosin heavy-chain fiber-type data collection, a minimum of 2 photomicrographs per section (minimum of 500 fibers per animal) were analyzed for isoform distribution with NIS-Elements Imaging Software (Basic Research, 3.3; Nikon Instruments Inc.). Fibers that were positively stained for the BA-D5 antibody were counted as primary muscle fibers, and the fibers that were positively stained for SC-71 were labeled as secondary fibers. Total muscle fiber number was calculated by dividing the whole muscle cross-sectional area by the average cross-sectional area of all muscle fibers. To calculate the total number of primary muscle fibers per muscle section, the percentage of primary muscle fibers was multiplied by the total number of muscle fibers. Similarly, the total number of secondary muscle fibers was calculated by multiplying the percentage of secondary fibers by the total number of muscle fibers.

\section{Statistical Analysis}

All data were analyzed as a generalized randomized complete block design using the GLIMMIX procedure 
Table 2. Analyzed dietary vitamin $\mathrm{D}_{3}$ in the complete diets, Exp. $1^{1}$

\begin{tabular}{lccccccc}
\hline \hline & \multicolumn{5}{c}{ Vitamin $\mathrm{D}_{3}, \mathrm{IU} / \mathrm{kg}$} \\
\cline { 2 - 7 } Item & 200 & 800 & 1,600 & 3,200 & 6,400 & 12,800 & 25,600 \\
\hline Formulated & 200 & 800 & 1,600 & 3,200 & 6,400 & 12,800 & 25,600 \\
Analyzed & 194 & 714 & 1,600 & 2,440 & 6,116 & 13,049 \\
Percentage of claim & 96.7 & 89.3 & 100.0 & 76.3 & 95.6 & 101.9 & 95.9 \\
\hline
\end{tabular}

${ }^{1}$ Samples were collected and pooled together, then shipped to a DSM Nutritional Products laboratory (Parsippany, NJ) for analysis. Means represent the average analyzed value of 2 samples.

of SAS (SAS Inst. Inc., Cary, NC). For Exp. 1, a mixed effect model was used to regress the sow serum $25(\mathrm{OH})$ $\mathrm{D}_{3}$ concentrations against dietary vitamin $\mathrm{D}_{3}$ concentrations per day. In the model, sow group was used as a random effect, and dietary treatment was used as the predictor variable. Fit of prediction models was evaluated by using the Bayesian information criterion (BIC). A model with a reduced BIC value of 2 or greater was considered an improved model (Kass and Raftery, 1995). Residuals during the model development process were evaluated to distinguish any potential biases in the prediction equations. Maternal performance data were analyzed with sow as the experimental unit, maternal treatment as a fixed effect, and farrowing group as a random effect. Responses not normally distributed were analyzed with a negative binomial distribution (total born and number after cross fostering), a binomial distribution (stillborns, mummies, and number born alive), or a $\beta$ distribution (bone ash). Preplanned comparisons consisted of 1) linear and quadratic polynomials for increasing vitamin $\mathrm{D}_{3}$ (Exp. 1 and 2), 2) $800 \mathrm{IU}$ vitamin $\mathrm{D}_{3}$ vs. $50 \mu \mathrm{g} 25(\mathrm{OH}) \mathrm{D}_{3}$ (Exp. 2), 3) 2,000 IU vitamin $\mathrm{D}_{3}$ vs. $50 \mu \mathrm{g} 25(\mathrm{OH}) \mathrm{D}_{3}$ (Exp. 2), and 4) 9,600 IU vitamin $\mathrm{D}_{3}$ vs. $50 \mu \mathrm{g} 25(\mathrm{OH}) \mathrm{D}_{3}$ (Exp. 2). The IML procedure of SAS was used to generate unequally spaced linear and quadratic contrast coefficients for dietary vitamin $\mathrm{D}_{3}$ treatments in Exp. 1 and 2. Additionally, the repeated measures analysis was performed on serum vitamin metabolite responses, and day of collection was included as a fixed effect to determine serum changes to dietary treatments over time. Results were considered significant at $P \leq 0.05$ and a tendency at $P \leq 0.10$.

\section{RESULTS AND DISCUSSION}

Supplementation of dietary vitamin $\mathrm{D}$ is required for swine reared in environmentally controlled production facilities because of the lack of exposure to direct sunlight needed for the endogenous conversion of 7-dehydrocholesterol to vitamin $\mathrm{D}_{3}$ in the skin. Previously documented cases of vitamin $\mathrm{D}$ being absent from premixes fed to pigs (Feedstuffs, 2010) has led to a resurgence of interest in the animal's requirement for vitamin D to safeguard from potential deficiency. Additionally, recent genomic data, which have shown the presence of the vitamin D receptor in many soft tissues not associated with normal $\mathrm{Ca}$ and $\mathrm{P}$ homeostasis (Norman and Bouillon, 2010), have led to increased efforts to understand vitamin D's role in other normal bodily processes. The aim of the current study was to evaluate maternal vitamin D supplementation as either vitamin $\mathrm{D}_{3}$ (at varying levels) or $25(\mathrm{OH}) \mathrm{D}_{3}$ on sow and subsequent pig response criteria.

\section{Experiment 1}

Although there is no published accepted standard for vitamin D recovery in animal feeds, analysis showed diets were within $25 \%$ of their formulated targets (Table 2). which would be consistent with the acceptable analytical variation and recovery of other vitamins previously discussed by the Association of American Feed Control Officials (AAFCO, 2015).

Gestating sows fed increasing vitamin $\mathrm{D}_{3}$ had increased (quadratic, $P=0.001$; Table 3 ) serum $25(\mathrm{OH}) \mathrm{D}_{3}$ concentrations. The serum results were used to develop an equation to predict the serum $25(\mathrm{OH}) \mathrm{D}_{3}$ response to increasing vitamin $\mathrm{D}_{3}$ supplementation in gestating females. The equation was as follows: serum $25(\mathrm{OH})$ $\mathrm{D}_{3}, \mathrm{ng} / \mathrm{mL}( \pm \mathrm{SE})=35.1746 \pm 5.56+(0.002353 \pm$ $0.00024 \times$ dietary vitamin $\left.\mathrm{D}_{3}, \mathrm{IU} / \mathrm{d}\right)-(0.0000000156 \pm$ $0.0000000036 \times$ dietary vitamin $\mathrm{D}_{3}, \mathrm{IU} / \mathrm{d}^{2}$; Fig. 1). Fitting a quadratic term model improved the BIC value compared with a single linear model, suggesting a better model fit to the observed data. To our knowledge, this

Table 3. Effects of increasing dietary vitamin $\mathrm{D}_{3}$ on serum $25(\mathrm{OH}) \mathrm{D}_{3}$ in gestating sows, Exp. $1^{1}$

\begin{tabular}{|c|c|c|c|c|c|c|c|c|c|c|}
\hline \multirow{2}{*}{$\begin{array}{l}\text { Serum } 25(\mathrm{OH}) \mathrm{D}^{3} \text {, } \\
\mathrm{ng} / \mathrm{mL}\end{array}$} & \multicolumn{7}{|c|}{ Vitamin $\mathrm{D}_{3}, \mathrm{IU} / \mathrm{kg}$} & \multirow[b]{2}{*}{ SEM } & \multicolumn{2}{|c|}{ Probability $P$, Vitamin $\mathrm{D}_{3}$} \\
\hline & 200 & 800 & 1,600 & 3,200 & 6,400 & 12,800 & 25,600 & & Linear & Quadratic \\
\hline $\mathrm{d} 0$ & 46.1 & 40.3 & 46.0 & 43.8 & 46.3 & 48.2 & 43.9 & 6.47 & $<0.826$ & $<0.318$ \\
\hline d 30 & 37.2 & 35.9 & 46.1 & 51.9 & 73.8 & 91.1 & 122.4 & 6.62 & $<0.001$ & $<0.001$ \\
\hline
\end{tabular}

${ }^{1} \mathrm{~A}$ total of 56 gestating sows were used in a $30-\mathrm{d}$ trial to determine the serum $25(\mathrm{OH}) \mathrm{D}_{3}$ response from feeding titrated concentrations of vitamin $\mathrm{D}_{3}$. There were 8 sows per treatment, and sows were fed $2.5 \mathrm{~kg} / \mathrm{d}$. 


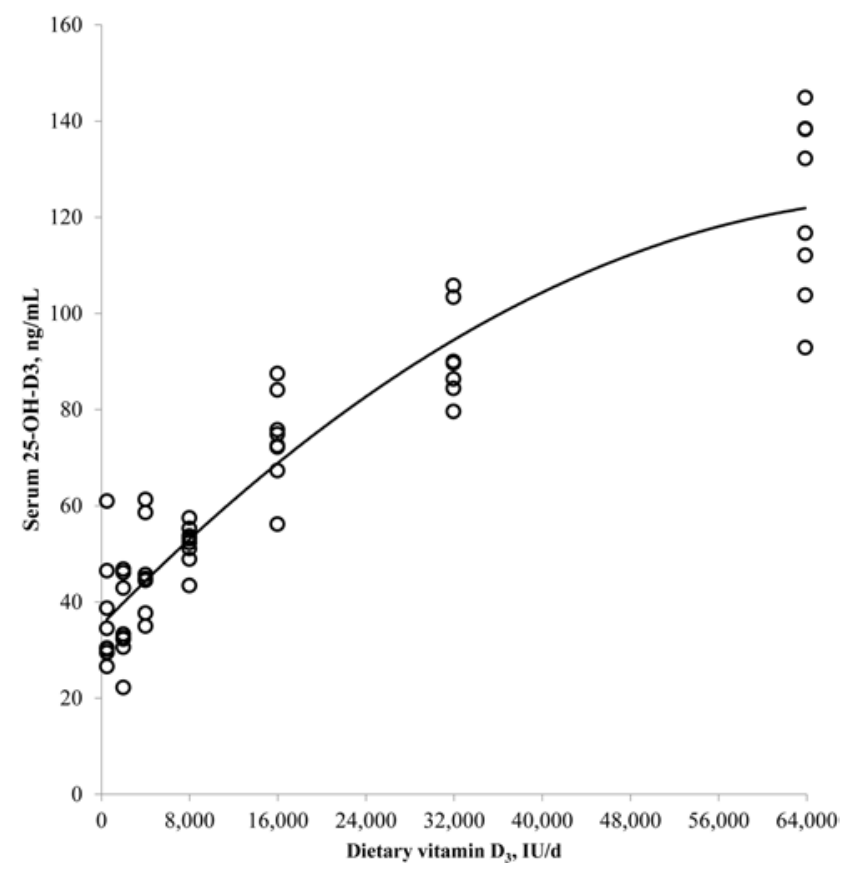

Figure 1. Plot of predicted serum $25(\mathrm{OH}) \mathrm{D}_{3}$ response to daily vitamin $\mathrm{D}_{3}$ intake of gestating sows (Exp. 1) based on the observed serum $25(\mathrm{OH}) \mathrm{D}_{3}$. The equation used for predicted values was serum $25(\mathrm{OH}) \mathrm{D}_{3}$, $\mathrm{ng} / \mathrm{mL}( \pm \mathrm{SE})=35.1746 \pm 5.56+(0.002353 \pm 0.00024 \times$ dietary vitamin $\left.\mathrm{D}_{3}, \mathrm{IU} / \mathrm{d}\right)-\left(0.0000000156 \pm 0.0000000034 \times\right.$ dietary vitamin $\left.\mathrm{D}_{3}, \mathrm{IU} / \mathrm{d}^{2}\right)$.

is the first study to develop a prediction equation based on dietary vitamin $\mathrm{D}$ intake in swine. This information was used to predict the vitamin $\mathrm{D}_{3}$ supplementation rate needed to achieve serum $25(\mathrm{OH}) \mathrm{D}_{3}$ results similar to that of sows fed a known amount of $25(\mathrm{OH}) \mathrm{D}_{3}$. Previous literature examining the serum $25(\mathrm{OH}) \mathrm{D}_{3}$ response of sows fed $50 \mu \mathrm{g} / \mathrm{kg}$ of $25(\mathrm{OH}) \mathrm{D}_{3}$ (Weber et al., 2014) in gestation concluded that the range of serum $25(\mathrm{OH})$ $\mathrm{D}_{3}$ response appeared to be between 50 and $90 \mathrm{ng} / \mathrm{mL}$ depending on time of sampling (gestation or lactation) and parity of the female. This range was supported by Lauridsen et al. (2010), who reported a mean serum $25(\mathrm{OH}) \mathrm{D}_{3}$ concentration of approximately $85 \mathrm{ng} / \mathrm{mL}$ for sows fed $50 \mu \mathrm{g}$ of $25(\mathrm{OH}) \mathrm{D}_{3} / \mathrm{kg}$ of diet. Additionally, Coffey et al. (2012) observed serum $25(\mathrm{OH}) \mathrm{D}_{3}$ concentrations of approximately 80 to $90 \mathrm{ng} / \mathrm{mL}$ for first-parity gestating gilts fed diets containing $50 \mu \mathrm{g}$ of $25(\mathrm{OH}) \mathrm{D}_{3} /$ $\mathrm{kg}$ along with $500 \mathrm{IU}$ of vitamin $\mathrm{D}_{3} / \mathrm{kg}$. In this preliminary experiment, we did not examine serum $25(\mathrm{OH})$ $\mathrm{D}_{3}$ concentrations from sows fed $50 \mu \mathrm{g}$ of $25(\mathrm{OH}) \mathrm{D}_{3} /$ $\mathrm{kg}$ because of the breadth of data supporting a response at approximately 70 to $80 \mathrm{ng} / \mathrm{mL}$ in the sow. Using the prediction equation developed herein, serum $25(\mathrm{OH})$ $\mathrm{D}_{3}$ concentrations between 50 and $90 \mathrm{ng} / \mathrm{mL}$ could be achieved by supplementing between 17,000 and 29,000 IU of vitamin $\mathrm{D}_{3} / \mathrm{d}$. To ensure the vitamin $\mathrm{D}_{3}$ supplementation rate was high enough to elicit a serum response similar to that reported in the literature when feeding 50 $\mu \mathrm{g} / \mathrm{kg}$ of $25(\mathrm{OH}) \mathrm{D}_{3}$, a targeted feeding level of $9,600 \mathrm{IU}$
Table 4. Analyzed sow diet composition, Exp. $2^{1}$

\begin{tabular}{|c|c|c|c|c|}
\hline \multirow[b]{3}{*}{ Item } & \multicolumn{4}{|c|}{ Maternal vitamin D supplementation, IU/kg } \\
\hline & \multicolumn{3}{|c|}{ Vitamin $\mathrm{D}_{3}$} & \multirow{2}{*}{$\begin{array}{c}50 \mu \mathrm{g} 25(\mathrm{OH}) \mathrm{D}_{3} \\
2,000\end{array}$} \\
\hline & 800 & 2,000 & 9,600 & \\
\hline \multicolumn{5}{|l|}{ Formulated gestation diets } \\
\hline $\mathrm{CP}, \%$ & 14.1 & 14.1 & 14.1 & 14.1 \\
\hline $\mathrm{Ca}, \%$ & 0.82 & 0.82 & 0.82 & 0.82 \\
\hline $\mathrm{P}, \%$ & 0.64 & 0.64 & 0.64 & 0.64 \\
\hline Vitamin $\mathrm{D}_{3}, \mathrm{IU} / \mathrm{kg}$ & 800 & 2,000 & 9,600 & - \\
\hline $25(\mathrm{OH}) \mathrm{D}_{3}, \mu \mathrm{g} / \mathrm{kg}$ & - & - & - & 50 \\
\hline \multicolumn{5}{|l|}{ Analyzed gestation diets } \\
\hline $\mathrm{CP}, \%$ & 15.0 & 15.2 & 14.8 & 14.8 \\
\hline $\mathrm{Ca}, \%$ & 1.01 & 0.86 & 0.87 & 1.06 \\
\hline $\mathrm{P}, \%$ & 0.62 & 0.62 & 0.64 & 0.63 \\
\hline Vitamin $\mathrm{D}_{3}, \mathrm{IU} / \mathrm{kg}$ & 730 & 2,000 & 9,057 & - \\
\hline $25(\mathrm{OH}) \mathrm{D}_{3}, \mu \mathrm{g} / \mathrm{kg}$ & - & - & - & 46.4 \\
\hline Vitamin D, \% of formulated & d 91.2 & 100.0 & 94.3 & 92.7 \\
\hline \multicolumn{5}{|l|}{ Formulated lactation diets } \\
\hline $\mathrm{CP}, \%$ & 19.9 & 19.9 & 19.9 & 19.9 \\
\hline $\mathrm{Ca}, \%$ & 0.83 & 0.83 & 0.83 & 0.83 \\
\hline $\mathrm{P}, \%$ & 0.70 & 0.70 & 0.70 & 0.70 \\
\hline Vitamin $\mathrm{D}_{3}, \mathrm{IU} / \mathrm{kg}$ & 800 & 2,000 & 9,600 & - \\
\hline $25(\mathrm{OH}) \mathrm{D}_{3}, \mu \mathrm{g} / \mathrm{kg}$ & - & - & - & 50 \\
\hline \multicolumn{5}{|l|}{ Analyzed lactation diets } \\
\hline $\mathrm{CP}, \%$ & 19.3 & 20.1 & 19.5 & 19.5 \\
\hline $\mathrm{Ca}, \%$ & 1.05 & 1.10 & 0.94 & 0.94 \\
\hline $\mathrm{P}, \%$ & 0.65 & 0.66 & 0.67 & 0.70 \\
\hline Vitamin $\mathrm{D}_{3}, \mathrm{IU} / \mathrm{kg}$ & 906 & 1,986 & 9,310 & - \\
\hline $25(\mathrm{OH}) \mathrm{D}_{3}, \mu \mathrm{g} / \mathrm{kg}$ & - & - & - & 45.4 \\
\hline Vitamin $D, \%$ of formulated & d113.1 & 99.3 & 97.0 & 90.7 \\
\hline
\end{tabular}

${ }^{1}$ Samples were collected and pooled together, then shipped to DSM Nutritional Products laboratory (Parsippany, NJ) for vitamin D analysis and to a commercial laboratory (Ward laboratories, Kearney, NE) for proximate analysis. Means represent the average analyzed value of 2 samples.

of vitamin $\mathrm{D}_{3}$ per kilogram of complete feed (12 to 14 times the NRC [2012] vitamin D requirement, approximately $24,000 \mathrm{IU} / \mathrm{d}$ ) was selected as the highest level of vitamin $\mathrm{D}_{3}$ supplementation for Exp. 2 .

\section{Experiment 2}

Proximate analysis of gestation and lactation diets fed in Exp. 2 (Table 4) showed CP and P concentrations similar to formulated levels. Analyzed Ca concentrations were more variable, but all values were above the requirements of the sow. Analysis showed diets were within $10 \%$ of their formulated targets, which is within the acceptable analytical variation and recovery of other vitamins (AAFCO, 2015).

\section{Sow Performance and Litter Characteristics}

Vitamin D treatment did not affect gestation $\mathrm{BW}$ gain (Table 5). Increasing vitamin $\mathrm{D}_{3}$ increased (quadratic, $P=0.011$ ) lactation ADFI and decreased 
Table 5. The effects of maternal dietary vitamin D supplementation on sow and preweaned pig performance, Exp. $2^{1}$

\begin{tabular}{|c|c|c|c|c|c|c|c|c|c|c|}
\hline \multirow[b]{3}{*}{ Item } & \multicolumn{4}{|c|}{ Maternal vitamin $\mathrm{D}, \mathrm{IU} / \mathrm{kg}$} & \multirow[b]{3}{*}{ SEM } & \multicolumn{5}{|c|}{ Probability, $P$} \\
\hline & \multicolumn{3}{|c|}{ Vitamin $\mathrm{D}_{3}$} & \multirow{2}{*}{$\frac{50 \mu \mathrm{g} 25(\mathrm{OH}) \mathrm{D}_{3}}{2,000}$} & & \multicolumn{2}{|c|}{ Vitamin $\mathrm{D}_{3}$} & \multirow{2}{*}{$\begin{array}{c}800 \mathrm{IU} \mathrm{D}_{3} \text { vs. } 50 \\
\mu \mathrm{g} 25(\mathrm{OH}) \mathrm{D}_{3}\end{array}$} & \multirow{2}{*}{$\begin{array}{c}2,000 \mathrm{IU} \mathrm{D}_{3} \text { vs. } \\
50 \mu \mathrm{g} 25(\mathrm{OH}) \mathrm{D}_{3} 5\end{array}$} & \multirow{2}{*}{$\begin{array}{l}9,600 \mathrm{IU} \mathrm{D}_{3} \text { vs. } \\
50 \mu \mathrm{g} 25(\mathrm{OH}) \mathrm{D}_{3}\end{array}$} \\
\hline & 800 & 2,000 & 9,600 & & & Linear & Quadratic & & & \\
\hline Sows, $n$ & 27 & 28 & 25 & 28 & - & - & - & - & - & - \\
\hline Parity & 2.2 & 2.2 & 2.1 & 2.2 & 0.30 & $<0.807$ & $<0.822$ & $<0.914$ & $<0.963$ & $<0.775$ \\
\hline Lactation ADFI, $\mathrm{kg}$ & 5.36 & 5.88 & 5.27 & 5.65 & 0.199 & $<0.137$ & $<0.011$ & $<0.184$ & $<0.294$ & $<0.088$ \\
\hline \multicolumn{11}{|l|}{ Sow BW, kg } \\
\hline \multicolumn{11}{|l|}{ Gestation } \\
\hline $\mathrm{d} 0$ & 193.2 & 190.8 & 190.4 & 192.0 & 9.55 & $<0.835$ & $<0.835$ & $<0.905$ & $<0.908$ & $<0.876$ \\
\hline d 110 & 234.7 & 226.1 & 233.7 & 233.9 & 7.85 & $<0.721$ & $<0.232$ & $<0.923$ & $<0.293$ & $<0.980$ \\
\hline $\mathrm{BW}$ gain, $\mathrm{kg}$ & 41.4 & 35.4 & 43.9 & 42.0 & 3.74 & $<0.330$ & $<0.190$ & $<0.901$ & $<0.191$ & $<0.771$ \\
\hline \multicolumn{11}{|l|}{ Lactation } \\
\hline $\mathrm{d} 0$ & 229.3 & 222.3 & 226.6 & 231.2 & 7.31 & $<0.909$ & $<0.348$ & $<0.800$ & $<0.231$ & $<0.547$ \\
\hline $\mathrm{d} 21$ & 221.2 & 221.8 & 220.5 & 227.0 & 6.94 & $<0.889$ & $<0.926$ & $<0.452$ & $<0.494$ & $<0.406$ \\
\hline BW loss, kg & -8.1 & -0.6 & -6.1 & -4.2 & 2.44 & $<0.677$ & $<0.003$ & $<0.129$ & $<0.153$ & $<0.464$ \\
\hline \multicolumn{11}{|l|}{ Sow back fat, mm } \\
\hline Farrowing & 14.3 & 13.5 & 14.9 & 14.1 & 0.72 & $<0.245$ & $<0.305$ & $<0.796$ & $<0.539$ & $<0.343$ \\
\hline Weaning & 12.7 & 12.5 & 13.3 & 12.6 & 0.63 & $<0.303$ & $<0.661$ & $<0.868$ & $<0.892$ & $<0.339$ \\
\hline Lactation back fat loss & -1.6 & -1.1 & -1.6 & -1.5 & 0.58 & $<0.734$ & $<0.395$ & $<0.876$ & $<0.516$ & $<0.883$ \\
\hline \multicolumn{11}{|l|}{ Litter characteristics } \\
\hline Total born, $n$ & 13.93 & 12.96 & 12.96 & 13.57 & 0.718 & $<0.584$ & $<0.573$ & $<0.783$ & $<0.645$ & $<0.652$ \\
\hline Born alive, $\%$ & 91.0 & 94.5 & 93.2 & 93.4 & 1.48 & $<0.763$ & $<0.329$ & $<0.428$ & $<0.651$ & $<0.929$ \\
\hline Stillborn, \% & 7.7 & 4.1 & 6.2 & 6.1 & 1.38 & $<0.956$ & $<0.294$ & $<0.534$ & $<0.447$ & $<0.958$ \\
\hline Mummies, \% & 1.3 & 1.4 & 0.6 & 0.5 & 0.61 & $<0.497$ & $<0.854$ & $<0.466$ & $<0.454$ & $<0.899$ \\
\hline Total after foster, $n$ & 12.00 & 11.29 & 11.53 & 11.76 & 0.706 & $<0.824$ & $<0.457$ & $<0.797$ & $<0.606$ & $<0.810$ \\
\hline Number weaned & 10.70 & 10.21 & 10.20 & 10.54 & 0.639 & $<0.761$ & $<0.698$ & $<0.880$ & $<0.773$ & $<0.770$ \\
\hline Survivability, \% & 89.5 & 90.8 & 88.8 & 88.9 & 2.27 & $<0.573$ & $<0.524$ & $<0.809$ & $<0.426$ & $<0.972$ \\
\hline \multicolumn{11}{|l|}{ Piglet BW, kg } \\
\hline Birth & 1.43 & 1.41 & 1.44 & 1.42 & 0.052 & $<0.816$ & $<0.842$ & $<0.989$ & $<0.989$ & $<0.770$ \\
\hline Weaning & 6.48 & 6.76 & 6.55 & 6.40 & 0.237 & $<0.882$ & $<0.349$ & $<0.231$ & $<0.231$ & $<0.622$ \\
\hline
\end{tabular}

${ }^{1} \mathrm{~A}$ total of 112 sows and litters were used to determine the effects of supplemental vitamin $\mathrm{D}$ from varying levels of vitamin $\mathrm{D}_{3}$ or from synthetic $25(\mathrm{OH})$ $\mathrm{D}_{3}$ on maternal performance, subsequent pig performance, sow and piglet serum vitamin metabolites, neonatal bone mineralization, and piglet muscle development. Three sows ( 1 from the $800 \mathrm{IU} / \mathrm{kg}$ treatment and 2 from the 9,600 IU/kg treatment) were removed because of farrowing complications. One sow from the treatment fed $9,600 \mathrm{IU} / \mathrm{kg}$ was removed from the data set due to a late-term abortion.

(quadratic, $P=0.003$ ) BW loss during lactation. This was because sows fed diets with 2,000 IU of vitamin $\mathrm{D}_{3} / \mathrm{kg}$ had greater lactation ADFI compared with sows fed diets with 800 or $9,600 \mathrm{IU}$ of vitamin $\mathrm{D}_{3} / \mathrm{kg}$. Also, sows consuming diets with $9,600 \mathrm{IU}$ vitamin $\mathrm{D}_{3} / \mathrm{kg}$ tended $(P=0.088)$ to have lower lactation feed intake compared with sows fed diets with $50 \mu \mathrm{g} / \mathrm{kg}$ of $25(\mathrm{OH})$ $\mathrm{D}_{3}$. Total daily vitamin $\mathrm{D}$ intake during lactation was approximately 4,300,11,800, and 50,600 IU/d for sows fed diets containing 800, 2,000, and 9,600 IU of vitamin $\mathrm{D}_{3} / \mathrm{kg}$, respectively, and approximately $11,300 \mathrm{IU} / \mathrm{d}$ for sows fed diets containing $50 \mu \mathrm{g} / \mathrm{kg}$ IU of $25(\mathrm{OH}) \mathrm{D}_{3} /$ $\mathrm{kg}$. The current study observed no impact of vitamin D treatment on litter characteristics or piglet BW at birth or weaning. The results herein suggest little to no influence of maternal vitamin D treatment above basal requirement on sow performance. Flohr et al. (2014) also concluded that varying vitamin $\mathrm{D}_{3}$ supplementation rates $(1,500$ to $6,000 \mathrm{IU} / \mathrm{kg}$ of diet) had no influence on sow performance or litter characteristics. However,
Lauridsen et al. (2010) observed reductions in stillborns from sows fed 1,400 or 2,000 IU of vitamin D/ $\mathrm{kg}$ of diet compared with sows fed 200 or 800 IU of vitamin $\mathrm{D} / \mathrm{kg}$ of diet. Weber et al. (2014) observed increases in the birth and weaning weight of pigs from sows fed $50 \mu \mathrm{g} / \mathrm{kg}$ of $25(\mathrm{OH}) \mathrm{D}_{3}$ compared with pigs from sows fed 2,000 IU of vitamin $\mathrm{D}_{3}$. They hypothesized that this was the result of improvements in the intrauterine development of the embryos. Coffey et al. (2012) observed an increase in the number of developed fetuses in the reproductive tracts of first-service gilts when supplemented with $25(\mathrm{OH}) \mathrm{D}_{3}$ rather than vitamin $\mathrm{D}_{3}$ at the same IU equivalency. Although some significant differences have been observed with different vitamin D supplementation strategies, the lack of consistency in measured responses across studies makes it difficult to determine whether vitamin D supplementation (above basal NRC, 2012, requirement) truly impacts maternal performance. Ultimately, commercial-scale studies with large sample sizes will be needed to increase sensitivity 
Table 6. The effects of maternal dietary vitamin D supplementation on sow serum metabolites, Exp. $2^{1}$

\begin{tabular}{|c|c|c|c|c|c|c|c|c|c|c|}
\hline \multirow{3}{*}{$\begin{array}{l}\text { Sow serum } \\
\text { vitamin metabolites }\end{array}$} & \multicolumn{4}{|c|}{ Maternal vitamin D, IU/kg } & \multicolumn{6}{|c|}{ Probability $P$} \\
\hline & \multicolumn{3}{|c|}{ Vitamin $\mathrm{D}_{3}$} & \multirow{2}{*}{$\begin{array}{c}50 \mu \mathrm{g} 25(\mathrm{OH}) \mathrm{D}_{3} \\
2,000\end{array}$} & \multirow[b]{2}{*}{$\mathrm{SEM}^{2}$} & \multicolumn{2}{|c|}{ Vitamin $D_{3}$} & \multirow{2}{*}{$\begin{array}{c}800 \text { IU D }_{3} \text { vs. } 50 \\
\mu \mathrm{g} 25(\mathrm{OH}) \mathrm{D}_{3}\end{array}$} & \multirow{2}{*}{$\begin{array}{c}2,000 \mathrm{IU} \mathrm{D} \mathrm{D}_{3} \text { vs. } \\
50 \mu \mathrm{g} 25(\mathrm{OH}) \mathrm{D}_{3}\end{array}$} & \multirow{2}{*}{$\begin{array}{c}9,600 \mathrm{IU} \mathrm{D}_{3} \text { vs. } \\
50 \mu \mathrm{g} 25(\mathrm{OH}) \mathrm{D}_{3}\end{array}$} \\
\hline & 800 & 2,000 & 9,600 & & & Linear & $\overline{\text { Quadratic }}$ & & & \\
\hline \multicolumn{11}{|l|}{$25(\mathrm{OH}) \mathrm{D}_{3},{ }^{3} \mathrm{ng} / \mathrm{mL}$} \\
\hline $\mathrm{d} 0$ of gestation & 44.6 & 43.9 & 41.1 & 45.9 & 3.54 & $<0.405$ & $<0.957$ & $<0.768$ & $<0.650$ & $<0.278$ \\
\hline d 100 of gestation & 27.6 & 29.2 & 82.5 & 59.5 & & $<0.001$ & $<0.157$ & $<0.001$ & $<0.001$ & $<0.001$ \\
\hline Farrowing & 25.1 & 26.1 & 68.2 & 55.4 & & $<0.001$ & $<0.241$ & $<0.001$ & $<0.001$ & $<0.004$ \\
\hline Weaning & 34.6 & 50.9 & 110.6 & 94.6 & & $<0.001$ & $<0.153$ & $<0.001$ & $<0.001$ & $<0.001$ \\
\hline \multicolumn{11}{|l|}{ Vitamin $\mathrm{D}_{3},{ }^{4} \mathrm{ng} / \mathrm{mL}$} \\
\hline \multicolumn{11}{|l|}{$\mathrm{d} 0$ of gestation } \\
\hline Detectable samples, $\%$ & 100.0 & 100.0 & 100.0 & 100.0 & 4.74 & $<0.999$ & $<0.999$ & $<0.999$ & $<0.999$ & $<0.999$ \\
\hline Serum $\mathrm{D}_{3}, \mathrm{ng} / \mathrm{mL}$ & 7.6 & 7.5 & 7.1 & 7.6 & 0.926 & $<0.677$ & $<0.965$ & $<0.954$ & $<0.877$ & $<0.646$ \\
\hline \multicolumn{11}{|l|}{ d 100 of gestation } \\
\hline Detectable samples, $\%$ & 100.0 & 100.0 & 100.0 & 100.0 & & $<0.999$ & $<0.999$ & $<0.999$ & $<0.999$ & $<0.999$ \\
\hline Serum $D_{3}, n g / m L$ & 3.5 & 5.2 & 26.6 & 1.9 & 0.926 & 0.001 & 0.217 & $<0.188$ & $<0.006$ & $<0.001$ \\
\hline \multicolumn{11}{|l|}{ Farrowing } \\
\hline Detectable samples, $\%$ & 100.0 & 100.0 & 100.0 & 91.7 & & $<0.999$ & $<0.999$ & $<0.216$ & $<0.216$ & $<0.216$ \\
\hline Serum $\mathrm{D}_{3}, \mathrm{ng} / \mathrm{mL}$ & 3.0 & 4.7 & 19.5 & 1.8 & 0.961 & $<0.001$ & $<0.645$ & $<0.357$ & $<0.020$ & $<0.001$ \\
\hline \multicolumn{11}{|l|}{ Weaning } \\
\hline Detectable samples, $\%$ & 91.7 & 100.0 & 100.0 & 58.3 & & $<0.387$ & $<0.255$ & $<0.001$ & $<0.001$ & $<0.001$ \\
\hline Serum $\mathrm{D}_{3}, \mathrm{ng} / \mathrm{mL}$ & 4.5 & 10.9 & 33.7 & 1.8 & 1.17 & $<0.001$ & $<0.035$ & $<0.063$ & $<0.001$ & 0.001 \\
\hline \multicolumn{11}{|l|}{$\alpha$-tocopherol, ${ }^{5} \mathrm{mg} / \mathrm{L}$} \\
\hline d 0 of gestation & 2,187 & 2,063 & 1,979 & 2,099 & 131.1 & $<0.275$ & $<0.545$ & $<0.601$ & $<0.830$ & $<0.473$ \\
\hline d 100 of gestation & 2,096 & 1,668 & 2,112 & 1,803 & & $<0.211$ & $<0.007$ & $<0.081$ & $<0.420$ & $<0.066$ \\
\hline Farrowing & 1,247 & 1,054 & 1,219 & 1,329 & & $<0.748$ & $<0.231$ & $<0.622$ & $<0.102$ & $<0.508$ \\
\hline Weaning & 2,338 & 2,611 & 2,295 & 2,358 & & $<0.305$ & $<0.077$ & $<0.905$ & $<0.132$ & $<0.705$ \\
\hline \multicolumn{11}{|l|}{ Retinol, ${ }^{6} \mathrm{ng} / \mathrm{mL}$} \\
\hline $\mathrm{d} 0$ of gestation & 285 & 294 & 254 & 279 & 17.6 & $<0.113$ & $<0.569$ & $<0.833$ & $<0.565$ & $<0.301$ \\
\hline d 100 of gestation & 231 & 210 & 237 & 225 & & $<0.492$ & $<0.353$ & $<0.807$ & $<0.554$ & $<0.604$ \\
\hline Farrowing & 128 & 165 & 149 & 192 & & $<0.593$ & $<0.713$ & $<0.177$ & $<0.291$ & $<0.089$ \\
\hline Weaning & 299 & 393 & 337 & 325 & & $<0.957$ & $<0.001$ & $<0.299$ & $<0.006$ & $<0.625$ \\
\hline
\end{tabular}

${ }^{1}$ In total 112 sows and litters were used to determine the effects of supplemental vitamin D from varying levels of vitamin $\mathrm{D}_{3}$ or from synthetic $25(\mathrm{OH})$ $\mathrm{D}_{3}$ on maternal performance, subsequent pig performance, sow and piglet serum vitamin metabolites, neonatal bone mineralization, and piglet muscle development. Means represent the average serum metabolite from 12 randomly selected sows within treatment and day combinations.

${ }^{2}$ Standard error of the mean representing the within-sampling day variation. Because the same number of treatments was analyzed for each day, the variance estimates were the same.

${ }^{3}$ A treatment $\times$ day interaction $(P=0.001)$ was observed for serum $25(\mathrm{OH}) \mathrm{D}_{3}$.

${ }^{4}$ The assay for serum vitamin $\mathrm{D}_{3}$ had a lower detectable limit of $1.00 \mathrm{ng} / \mathrm{mL}$. Samples below the detectable limit $(n=144$ out of 192$)$ were not used in the statistical analysis. Detectable samples represent the percentage of samples above the detectable limit, and the mean serum vitamin $\mathrm{D}_{3}$ was calculated using only samples above the detectable limit.

${ }^{5}$ A tendency $(P=0.052)$ for a treatment $\times$ day interaction was observed for serum $\boldsymbol{\alpha}$-tocopherol.

${ }^{6} \mathrm{~A}$ treatment $\times$ day interaction $(P=0.035)$ was observed for serum retinol.

and reduce the experimental error associated with sow reproduction measurements to evaluate dietary supplementation of vitamin D above the current requirement.

\section{Sow Serum 25(OH)D, Vitamin $D_{3}$, $\alpha$-Tocopherol, and Retinol}

A treatment $\times$ day interaction $(P=0.001$; Table 6$)$ for serum $25(\mathrm{OH}) \mathrm{D}_{3}$ of sows was observed because sow serum $25(\mathrm{OH}) \mathrm{D}_{3}$ was similar on $\mathrm{d} 0$ of gestation regardless of dietary vitamin $\mathrm{D}$ treatment, but increasing vitamin $\mathrm{D}_{3}$ increased (linear, $P<0.001$ ) serum $25(\mathrm{OH}) \mathrm{D}_{3}$ on $\mathrm{d} 100$ of gestation, after farrowing, and at weaning. Also, sows fed diets with 800 or $2,000 \mathrm{IU}$ of vitamin $\mathrm{D}_{3} / \mathrm{kg}$ had less serum $25(\mathrm{OH}) \mathrm{D}_{3}$ on $\mathrm{d} 100$ of gestation $(P=0.001)$, after farrowing $(P=0.001)$, and at weaning $(P=0.001)$ compared with sows fed $50 \mu \mathrm{g}$ of $25(\mathrm{OH}) \mathrm{D}_{3} / \mathrm{kg}$. Sows fed the diets with $9,600 \mathrm{IU}$ of vitamin $\mathrm{D}_{3} / \mathrm{kg}$ had greater serum $25(\mathrm{OH}) \mathrm{D}_{3}$ concentrations on $\mathrm{d} 100$ of gestation $(P=0.001)$, after farrowing $(P=0.004)$, and at weaning $(P=0.001)$ compared with sows fed $25(\mathrm{OH}) \mathrm{D}_{3}$. Lauridsen et al. (2010), Coffey et al. (2012), and Weber et al. (2014) have all discussed similar responses when comparing the supplementation of $25(\mathrm{OH}) \mathrm{D}_{3}$ and vitamin $\mathrm{D}_{3}$ at the same IU equivalency. It is clear that $25(\mathrm{OH}) \mathrm{D}_{3}$ provides a greater serum 
Table 7. The effect of maternal dietary vitamin D supplementation on preweaned pig serum vitamin metabolites and neonatal bone ash, Exp. $2^{1,2}$

\begin{tabular}{|c|c|c|c|c|c|c|c|c|c|c|}
\hline \multirow[b]{3}{*}{ Item } & \multicolumn{4}{|c|}{ Maternal vitamin $\mathrm{D}, \mathrm{IU} / \mathrm{kg}$} & \multirow{3}{*}{$\mathrm{SEM}^{2}$} & \multicolumn{5}{|c|}{ Probability $P$} \\
\hline & \multicolumn{3}{|c|}{ Vitamin $\mathrm{D}_{3}$} & \multirow{2}{*}{$\frac{50 \mu \mathrm{g} 25(\mathrm{OH}) \mathrm{D}_{3}}{2,000}$} & & \multicolumn{2}{|c|}{ Vitamin $\mathrm{D}_{3}$} & \multirow{2}{*}{$\begin{array}{c}800 \text { IU D }_{3} \text { vs. } 50 \\
\mu \mathrm{g} 25(\mathrm{OH}) \mathrm{D}_{3}\end{array}$} & \multirow{2}{*}{$\begin{array}{c}2,000 \mathrm{IU} \mathrm{D}_{3} \text { vs. } \\
50 \mu \mathrm{g} 25(\mathrm{OH}) \mathrm{D}_{3}\end{array}$} & \multirow{2}{*}{$\begin{array}{c}9,600 \mathrm{IU} \mathrm{D}_{3} \mathrm{vs} . \\
50 \mu \mathrm{g} 25(\mathrm{OH}) \mathrm{D}_{3}\end{array}$} \\
\hline & 800 & 2,000 & 9,600 & & & Linear & Quadratic & & & \\
\hline \multicolumn{11}{|c|}{ Preweaned pig serum vitamin metabolites } \\
\hline \multicolumn{11}{|c|}{$25(\mathrm{OH}) \mathrm{D}_{3},{ }^{3} \mathrm{ng} / \mathrm{mL}$} \\
\hline Birth & 2.0 & 2.2 & 5.5 & 3.5 & 0.43 & $<0.001$ & $<0.548$ & $<0.004$ & $<0.011$ & $<0.001$ \\
\hline Weaning & 4.3 & 7.0 & 16.3 & 6.1 & 0.43 & $<0.001$ & $<0.033$ & $<0.001$ & $<0.101$ & $<0.001$ \\
\hline \multicolumn{11}{|l|}{ Vitamin $\mathrm{D}_{3}^{4}$} \\
\hline \multicolumn{11}{|l|}{ Birth } \\
\hline Detectable samples, $\%$ & 0.0 & 0.0 & 54.2 & 0.0 & 5.61 & $<0.001$ & $<0.299$ & $<0.999$ & $<0.999$ & $<0.001$ \\
\hline Serum vitamin $\mathrm{D}_{3}, \mathrm{ng} / \mathrm{mL}$ & - & - & 1.7 & - & 0.45 & - & - & - & - & - \\
\hline \multicolumn{11}{|l|}{ Weaning } \\
\hline Detectable samples, $\%$ & 0.0 & 41.7 & 100 & 4.2 & 5.61 & $<0.001$ & $<0.001$ & $<0.582$ & $<0.001$ & $<0.001$ \\
\hline Serum vitamin $\mathrm{D}_{3}, \mathrm{ng} / \mathrm{mL}$ & - & 1.4 & 5.7 & 2.1 & 1.24 & - & - & - & - & - \\
\hline \multicolumn{11}{|l|}{$\alpha$-tocopherol, mg/L } \\
\hline Birth & 2,718 & 2,494 & 2,190 & 2,662 & 395.9 & $<0.319$ & $<0.757$ & $<0.912$ & $<0.741$ & $<0.342$ \\
\hline Weaning & 5,331 & 4,584 & 5,379 & 4,844 & 380.2 & $<0.439$ & $<0.107$ & $<0.326$ & $<0.601$ & $<0.286$ \\
\hline \multicolumn{11}{|l|}{ Retinol, ${ }^{5} \mathrm{ng} / \mathrm{mL}$} \\
\hline Birth & 108 & 80 & 93 & 106 & 9.6 & $<0.714$ & $<0.031$ & $<0.909$ & $<0.038$ & $<0.288$ \\
\hline Weaning & 254 & 266 & 268 & 255 & 9.6 & $<0.395$ & $<0.384$ & $<0.924$ & $<0.381$ & $<0.305$ \\
\hline \multicolumn{11}{|l|}{ Bone ash content, $\%$} \\
\hline Second rib & 53.7 & 55.7 & 54.0 & 54.0 & 3.11 & $<0.753$ & $<0.265$ & $<0.863$ & $<0.358$ & $<0.973$ \\
\hline Femur & 46.1 & 45.6 & 45.5 & 46.4 & 0.53 & $<0.519$ & $<0.566$ & $<0.681$ & $<0.285$ & $<0.246$ \\
\hline
\end{tabular}

${ }^{1}$ In total 112 sows and litters were used to determine the effects of supplemental vitamin $\mathrm{D}$ from varying levels of vitamin $\mathrm{D}_{3}$ or from synthetic $25(\mathrm{OH})$ $\mathrm{D}_{3}$ on maternal performance, subsequent pig performance, sow and piglet serum vitamin metabolites, neonatal bone mineralization, and piglet muscle development. Means represent the average serum metabolite from 48 randomly selected litters (2 pigs per litter were bled for serum analysis) within treatments, and the same litters within each day were analyzed. One pig per litter $(n=104)$ was euthanized for bone ash percentage determination.

${ }^{2}$ Standard error of the mean representing the within-sampling day variation. Because the same number of treatments was analyzed for each day, the variance estimates were the same.

${ }^{3}$ A treatment $\times$ day interaction $(P=0.001)$ was observed for serum $25(\mathrm{OH}) \mathrm{D}_{3}$.

${ }^{4}$ The assay for serum vitamin $\mathrm{D}_{3}$ had a lower detectable limit of $1.00 \mathrm{ng} / \mathrm{mL}$. Samples below the detectable limit $(n=144$ out of 192$)$ were not used in the statistical analysis. Detectable sample represents the percentage of samples above the detectable limit, and the mean serum vitamin $\mathrm{D}_{3}$ was calculated using only samples above the detectable limit.

${ }^{5} \mathrm{~A}$ tendency $(P=0.065)$ for a treatment $\times$ day interaction was observed for serum retinol.

$25(\mathrm{OH}) \mathrm{D}_{3}$ response in sows. Although the exact reason for this improved response is not completely clear, Bar et al. (1980) demonstrated that $25(\mathrm{OH}) \mathrm{D}_{3}$ is absorbed more efficiently than vitamin $\mathrm{D}_{3}$ in the upper portion of the intestine of young broiler chicks. Another potential reason may be due to the postabsorptive transport of the different forms. Because $25(\mathrm{OH}) \mathrm{D}_{3}$ is the circulating form of the vitamin that binds with the vitamin $\mathrm{D}$ binding protein in the bloodstream, it does not require the hydroxylation step of metabolism in the liver. On the other hand, vitamin $\mathrm{D}_{3}$ must enter the bloodstream as a part of a chylomicron (Clinton, 2013). Lipoprotein lipases in adipose tissue can interact with circulating chylomicrons to store a portion of their lipids and, consequently, the vitamin $\mathrm{D}_{3}$ transported within them. This suggests that a portion of the vitamin $\mathrm{D}_{3}$ that is absorbed may be stored in adipose tissue rather than being transported to the liver for hydroxylation. The serum $25(\mathrm{OH})$ $\mathrm{D}_{3}$ concentrations achieved in gestation from supple- menting $25(\mathrm{OH}) \mathrm{D}_{3}$ were less than those in the reports of previous researchers (Lauridsen et al., 2010; Coffey et al., 2012; Weber et al., 2014); this may be due to the time of sampling and duration of feeding, which Weber et al. (2014) discussed as potential influencers of the serum response. Also, Lauridsen et al. (2010) summarized results using only the main effect of dietary treatment on serum $25(\mathrm{OH}) \mathrm{D}_{3}$ concentrations from sows fed 50 $\mu \mathrm{g}$ of $25(\mathrm{OH}) \mathrm{D}_{3} / \mathrm{kg}$ rather than reporting the interactive means of time $\times$ dietary treatment, which may have led to an inflated mean serum concentration due to increased vitamin intake during the lactation period. The increases in serum $25(\mathrm{OH}) \mathrm{D}_{3}$ with increasing vitamin $\mathrm{D}_{3}$ agree with previous data from Flohr et al. (2014). To our knowledge, this is the first study that has shown a level of vitamin $\mathrm{D}_{3}$ supplementation that has elicited a serum response above feeding $50 \mu \mathrm{g}$ of $25(\mathrm{OH}) \mathrm{D}_{3} / \mathrm{kg}$.

For serum vitamin $\mathrm{D}_{3}$, maternal vitamin $\mathrm{D}$ treatment did not affect the percentage of sows exhibiting serum 
Table 8. The effect of maternal dietary vitamin D supplementation on neonatal muscle immunohistochemistry, Exp. $2^{1}$

\begin{tabular}{|c|c|c|c|c|c|c|c|c|c|c|}
\hline \multirow[b]{3}{*}{ Item } & \multicolumn{4}{|c|}{ Maternal vitamin D, IU/kg } & \multirow{3}{*}{ SEM } & \multicolumn{5}{|c|}{ Probability $P$} \\
\hline & \multicolumn{3}{|c|}{ Vitamin $\mathrm{D}_{3}$} & \multirow{2}{*}{$\frac{50 \mu \mathrm{g} 25(\mathrm{OH}) \mathrm{D}_{3}}{2,000}$} & & \multicolumn{2}{|c|}{ Vitamin $\mathrm{D}_{3}$} & \multirow{2}{*}{$\begin{array}{c}800 \mathrm{IU} \mathrm{D}_{3} \text { vs. } 50 \\
\mu \mathrm{g} 25(\mathrm{OH}) \mathrm{D}_{3}\end{array}$} & \multirow{2}{*}{$\begin{array}{l}2,000 \mathrm{IU} \mathrm{D}_{3} \text { vs. } \\
50 \mu \mathrm{g} 25(\mathrm{OH}) \mathrm{D}_{3}\end{array}$} & \multirow{2}{*}{$\begin{array}{l}9,600 \mathrm{IU} \mathrm{D}_{3} \text { vs. } \\
50 \mu \mathrm{g} 25(\mathrm{OH}) \mathrm{D}_{3}\end{array}$} \\
\hline & 800 & 2,000 & 9,600 & & & Linear & Quadratic & & & \\
\hline Litters sampled, $n$ & 25 & 27 & 25 & 27 & & & & & & \\
\hline \multicolumn{11}{|l|}{ Longissimus thoracis } \\
\hline Whole muscle area, ${ }^{2} \mathrm{~mm}^{2}$ & 117.3 & 113.7 & 113.5 & 111 & 13.98 & $<0.795$ & $<0.749$ & $<0.543$ & $<0.792$ & $<0.810$ \\
\hline Average fiber $\mathrm{CSA},{ }^{3} \mu \mathrm{m}^{2}$ & 101.1 & 106.4 & 96.8 & 109.8 & 9.56 & $<0.291$ & $<0.362$ & $<0.200$ & $<0.609$ & $<0.057$ \\
\hline Average primary fiber $\mathrm{CSA},{ }^{4} \mu \mathrm{m}^{2}$ & 191.5 & 209.7 & 197.7 & 213.4 & 11.47 & $<0.946$ & $<0.254$ & $<0.173$ & $<0.813$ & $<0.325$ \\
\hline Average secondary fiber CSA,${ }^{5} \mu \mathrm{m}^{2}$ & 95.8 & 99.8 & 91.0 & 102.9 & 9.52 & $<0.272$ & $<0.450$ & $<0.276$ & $<0.632$ & $<0.070$ \\
\hline Total fiber number ${ }^{6}\left(1 \times 10^{6}\right)$ & 1.2 & 1.1 & 1.3 & 1.1 & 0.18 & $<0.540$ & $<0.296$ & $<0.235$ & $<0.823$ & $<0.177$ \\
\hline Total primary fibers ${ }^{7}\left(1 \times 10^{4}\right)$ & 6.8 & 6.9 & 6.5 & 8.5 & 1.06 & $<0.776$ & $<0.924$ & $<0.234$ & $<0.254$ & $<0.158$ \\
\hline Total secondary fibers ${ }^{8}\left(1 \times 10^{6}\right)$ & 1.8 & 1.1 & 1.2 & 1.0 & 0.17 & $<0.502$ & $<0.270$ & $<0.169$ & $<0.716$ & $<0.117$ \\
\hline Secondary:primary 9 & 18.0 & 16.5 & 18.8 & 15.7 & 1.63 & $<0.289$ & $<0.238$ & $<0.112$ & $<0.577$ & $<0.035$ \\
\hline \multicolumn{11}{|l|}{ Semitendinosus } \\
\hline Whole muscle area, ${ }^{2} \mathrm{~mm}^{2}$ & 60.0 & 64.3 & 61.6 & 62.0 & 7.30 & $<0.985$ & $<0.460$ & $<0.730$ & $<0.695$ & $<0.939$ \\
\hline Average fiber CSA, ${ }^{3} \mu \mathrm{m}^{2}$ & 135.4 & 139.7 & 128.8 & 140.4 & 10.89 & $<0.409$ & $<0.633$ & $<0.671$ & $<0.954$ & $<0.303$ \\
\hline Average primary fiber $\mathrm{CSA},{ }^{4} \mu \mathrm{m}^{2}$ & 185.4 & 198.7 & 171.8 & 202.9 & 12.47 & $<0.142$ & $<0.279$ & $<0.243$ & $<0.767$ & $<0.031$ \\
\hline Average secondary fiber $\mathrm{CSA},{ }^{5} \mu \mathrm{m}^{2}$ & 131.7 & 135.8 & 125.7 & 136.2 & 10.59 & $<0.449$ & $<0.656$ & $<0.700$ & $<0.968$ & $<0.349$ \\
\hline Total fiber number ${ }^{6}\left(1 \times 10^{5}\right)$ & 4.7 & 4.6 & 4.8 & 4.7 & 0.54 & $<0.771$ & $<0.799$ & $<0.949$ & $<0.875$ & $<0.810$ \\
\hline Total primary fibers ${ }^{7}\left(1 \times 10^{4}\right)$ & 3.5 & 3.5 & 3.4 & 3.6 & 0.54 & $<0.822$ & $<0.923$ & $<0.905$ & $<0.957$ & $<0.766$ \\
\hline Total secondary fibers ${ }^{8}\left(1 \times 10^{5}\right)$ & 4.4 & 4.3 & 4.5 & 4.4 & 0.51 & $<0.739$ & $<0.775$ & $<0.932$ & $<0.871$ & $<0.773$ \\
\hline Secondary:primary 9 & 15.5 & 19.7 & 16.9 & 18.1 & 3.83 & $<0.943$ & $<0.312$ & $<0.544$ & $<0.688$ & $<0.769$ \\
\hline
\end{tabular}

${ }^{1}$ In total 112 sows and their subsequent litters were used to evaluate the effects of maternal vitamin D supplementation on fetal muscle development. For all litters larger than 6 pigs, 1 pig per litter (the male piglet closest to the mean BW within $24 \mathrm{~h}$ of birth) was euthanized for muscle fiber identification.

${ }^{2}$ Cross-sectional area of the whole muscle.

${ }^{3}$ Average cross-sectional area of all muscle fibers.

${ }^{4}$ Average cross-sectional area of a representative sample of primary muscle fibers.

${ }^{5}$ Average cross-sectional area of a representative sample of secondary muscle fibers.

${ }^{6}$ Total muscle fiber number is calculated as the whole muscle area divided by the average muscle fiber cross-sectional area of all muscle fibers.

${ }^{7}$ Total primary muscle fiber number was calculated as the percentage of primary fibers $\times$ total fiber number.

${ }^{8}$ Total secondary muscle fiber number was calculated as the percentage of secondary fibers $\times$ total fiber number.

${ }^{9}$ The average number of secondary muscle fibers per primary muscle fiber.

concentrations above the detectable limit on d 0 or 100 of gestation or at farrowing. However, at weaning, greater percentages of sows fed vitamin $\mathrm{D}_{3}(P<0.001)$ had serum vitamin $\mathrm{D}_{3}$ concentrations above the detectable limit. Increasing vitamin $\mathrm{D}_{3}$ increased serum vitamin $\mathrm{D}_{3}$ on d 100 of gestation (linear, $P=0.001$ ), after farrowing (linear, $P=0.001$ ), and at weaning (quadratic, $P=$ 0.035 ). Also, sows fed the diets with 2,000 or $9,600 \mathrm{IU}$ of vitamin $\mathrm{D}_{3} / \mathrm{kg}$ had greater serum vitamin $\mathrm{D}_{3}$ concentrations on d 100 of gestation $(P<0.006)$, after farrowing $(P<0.020)$, and at weaning $(P=0.001)$ compared with sows fed $25(\mathrm{OH}) \mathrm{D}_{3}$. Sows fed diets containing $800 \mathrm{IU}$ of vitamin $\mathrm{D}_{3} / \mathrm{kg}$ tended to have greater $(P=0.063)$ serum vitamin $\mathrm{D}_{3}$ concentrations at weaning compared with sows fed diets with $50 \mu \mathrm{g} / \mathrm{kg}$ of $25(\mathrm{OH}) \mathrm{D}_{3}$. Serum vitamin $\mathrm{D}_{3}$ is typically much more variable than $25(\mathrm{OH}) \mathrm{D}_{3}$ since it will increase rapidly after exposure (either in the diet or through the skin) and will be cleared from circulation by the liver or storage tissue within hours. Also, the vitamin $\mathrm{D}$ binding protein, which accompanies vitamin D metabolites in circulation, has a much lower affinity for vitamin $\mathrm{D}_{3}$ compared with $25(\mathrm{OH}) \mathrm{D}_{3}$ (Institute of Medicine, 2011). In the current study, it is understandable that increasing dietary vitamin $\mathrm{D}_{3}$ led to increased serum concentrations of the nutrient. Additionally, because of less vitamin $\mathrm{D}_{3}$ exposure of sows fed $25(\mathrm{OH})$ $\mathrm{D}_{3}$, it is justified that their serum vitamin $\mathrm{D}_{3}$ was lower than that of sows fed vitamin $\mathrm{D}_{3}$.

There was a tendency $(P=0.052)$ for a treatment $\times$ day interaction for sow serum $\alpha$-tocopherol concentrations because serum $\alpha$-tocopherol was similar across maternal treatments on $\mathrm{d} 0$ of gestation and after farrowing, but on 100 of gestation increasing vitamin $D_{3}$ supplementation decreased (quadratic, $P=0.007$ ) serum $\alpha$-tocopherol concentrations. Additionally, on d 100 of gestation, serum $\alpha$-tocopherol tended $(P<0.081)$ to be greater for sows fed 800 or $9,600 \mathrm{IU}$ of vitamin $\mathrm{D}_{3} / \mathrm{kg}$ compared with sows fed $50 \mu \mathrm{g}$ of $25(\mathrm{OH}) \mathrm{D}_{3} / \mathrm{kg}$. These differences observed in serum $\alpha$-tocopherol were unexpected since all diets were formulated to contain similar concentrations of vitamin E (66 IU/ $/ \mathrm{kg}$ of diet), resulting in a daily intake of $165 \mathrm{IU}$ of vitamin E. Additionally, 
there are no previous data that have evaluated a vitamin $\mathrm{E}$ and vitamin $\mathrm{D}$ interaction in livestock diets. However, Goncalves et al. (2015) concluded that there is the potential for common absorption pathways for vitamin D and E since increasing vitamin D uptake resulted in decreased vitamin E uptake in human epithelial colorectal adenocarcinoma cells (Caco-2) in vitro cells. At weaning, there was a tendency (quadratic, $P=0.077$ ) for sows fed increasing vitamin $\mathrm{D}_{3}$ to have increasing serum $\alpha$-tocopherol. This tendency for increased serum $\alpha$-tocopherol may be the result of increased lactation feed intake observed for sows fed 2,000 IU of vitamin $\mathrm{D}_{3} / \mathrm{kg}$. On the basis of lactation feed intake, sows consuming diets with $2,000 \mathrm{IU}$ of vitamin $\mathrm{D}_{3} / \mathrm{kg}$ had vitamin E intakes of approximately $390 \mathrm{IU} / \mathrm{d}$, compared with sows fed either 800 or $9,600 \mathrm{IU}$ of vitamin $\mathrm{D}_{3} / \mathrm{kg}$, which had vitamin $E$ intakes of approximately $350 \mathrm{IU} / \mathrm{d}$.

A treatment $\times$ day interaction $(P=0.001)$ for sow serum retinol was observed because serum retinol was similar regardless of maternal vitamin $\mathrm{D}$ treatment on $\mathrm{d}$ 0 and 100 of gestation; however, after farrowing, sows fed $9,600 \mathrm{IU}$ of vitamin $\mathrm{D}_{3} / \mathrm{kg}$ tended $(P=0.089)$ to have less serum retinol compared with sows fed $50 \mu \mathrm{g}$ of $25(\mathrm{OH}) \mathrm{D}_{3} / \mathrm{kg}$. In addition, sows fed increasing levels of vitamin $\mathrm{D}_{3}$ had increased (quadratic, $P=0.001$ ) serum retinol concentrations at weaning. Sows fed diets with 2,000 IU of vitamin $\mathrm{D}_{3} / \mathrm{kg}$ had greater $(P=0.006)$ serum retinol compared with sows fed $50 \mu \mathrm{g}$ of $25(\mathrm{OH})$ $\mathrm{D}_{3} / \mathrm{kg}$ at weaning. Again, this increase in serum retinol at weaning was likely the result of increased vitamin A intake for sows fed the diets with 2,000 IU of vitamin $\mathrm{D}_{3} /$ $\mathrm{kg}$ because of the increase in lactation feed intake. Sows consuming diets with 2,000 IU of vitamin $\mathrm{D}_{3}$ consumed approximately $6,500 \mathrm{IU}$ of vitamin A/D compared with sows fed $800 \mathrm{IU}$ of vitamin $\mathrm{D}_{3} / \mathrm{kg}$ (approximate vitamin A intake of 5,900 IU/d), sows fed 9,600 IU of vitamin $\mathrm{D}_{3} / \mathrm{kg}$ (approximate vitamin A intake of 5,800 IU/d), and sows fed $50 \mu \mathrm{g}$ of $25(\mathrm{OH}) \mathrm{D}_{3} / \mathrm{kg}$ (approximate vitamin A intake of 6,225 IU/d). Little information has been reported on the interactions of vitamin A and vitamin D. Abawi and Sullivan (1989) concluded that supplying higher supplemental levels of vitamin D helped improve performance in broilers supplemented high levels of vitamin A and E. Also, Payne and Manston (1967) concluded that increasing the supplementation of vitamin A with high supplementation of vitamin D may reduce the chance of vitamin D toxicity.

\section{Piglet Serum 25(OH) $D_{3}$, Vitamin $D_{3}, \alpha$-Tocopherol, Retinol, and Neonatal Percentage Bone Ash}

For piglet serum $25(\mathrm{OH}) \mathrm{D}_{3}$, there was a treatment $\times$ day interaction $(P=0.001$; Table 7$)$ because increasing maternal dietary vitamin $\mathrm{D}_{3}$ increased (linear, $P<$
$0.001)$ piglet serum $25(\mathrm{OH}) \mathrm{D}_{3}$ at birth and at weaning (quadratic, $P=0.033$ ), with a greater magnitude of increase occurring at weaning. This observation agrees with reports from Flohr et al. (2014), who found that increasing maternal vitamin $\mathrm{D}_{3}$ supplementation from 1,500 to $6,000 \mathrm{IU} / \mathrm{kg}$ of diet increased subsequent piglet serum $25(\mathrm{OH}) \mathrm{D}_{3}$ throughout lactation. Also, in the current study, piglets from sows fed $25(\mathrm{OH}) \mathrm{D}_{3}$ had greater $(P<0.011)$ serum $25(\mathrm{OH}) \mathrm{D}_{3}$ compared with piglets from sows fed 800 or $2,000 \mathrm{IU}$ of vitamin $\mathrm{D}_{3} / \mathrm{kg}$ at birth; however, at weaning, piglets from sows fed $50 \mu \mathrm{g}$ of $25(\mathrm{OH}) \mathrm{D}_{3} / \mathrm{kg}$ had similar serum $25(\mathrm{OH}) \mathrm{D}_{3}$ compared with piglets from sows fed the $2,000 \mathrm{IU}$ of vitamin $\mathrm{D}_{3} /$ $\mathrm{kg}$ and greater $(P=0.001)$ serum $25(\mathrm{OH}) \mathrm{D}_{3}$ concentrations compared with piglets from sows fed 800 IU of vitamin $\mathrm{D}_{3} / \mathrm{kg}$. Additionally, piglets from sows fed 9,600 IU of vitamin $\mathrm{D}_{3} / \mathrm{kg}$ had increased $(P=0.001)$ serum $25(\mathrm{OH}) \mathrm{D}_{3}$ at birth and weaning compared with piglets from sows fed $50 \mu \mathrm{g} / \mathrm{kg}$ of $25(\mathrm{OH}) \mathrm{D}_{3} / \mathrm{kg}$.

Previous reports from Coffey et al. (2012) and Witschi et al. (2011) have discussed increases in serum $25(\mathrm{OH}) \mathrm{D}_{3}$ concentrations in fetuses (d 90 of gestation) and piglets from sows supplemented dietary $25(\mathrm{OH}) \mathrm{D}_{3}$ compared with those from sows supplemented with dietary vitamin $\mathrm{D}_{3}$ at the same IU equivalency. Goff et al. (1984) demonstrated that the $25(\mathrm{OH}) \mathrm{D}_{3}$ of the neonate is largely correlated to the $25(\mathrm{OH}) \mathrm{D}_{3}$ status of the sow at birth, and $25(\mathrm{OH}) \mathrm{D}_{3}$ has clearly been demonstrated as the vitamin D metabolite associated with transplacental transfer (Haddad et al., 1971). The current data agree with previous reports and are the first to show a maternal dietary vitamin $\mathrm{D}_{3}$ supplementation rate that provided a larger serum $25(\mathrm{OH}) \mathrm{D}_{3}$ response in piglets compared with piglets from sows supplemented $50 \mu \mathrm{g}$ of $25(\mathrm{OH}) \mathrm{D}_{3}$. Human research has shown that the transfer of vitamin D metabolites into breast milk is limited (Hollis and Wagner, 2004). Flohr et al. (2014) concluded that increasing supplementation of vitamin $\mathrm{D}_{3}$ led to increasing milk vitamin $\mathrm{D}_{3}$ concentrations throughout a 21-d lactation period when milk samples were taken immediately after parturition (colostrum), on d 10, and at weaning. Clements and Fraser (1988) reported that vitamin $\mathrm{D}_{3}$ was the predominant vitamin $\mathrm{D}$ constituent in colostrum of rats, but vitamin $\mathrm{D}_{3}$ concentrations declined after a few days, and $25(\mathrm{OH}) \mathrm{D}_{3}$ became the predominant metabolite in milk. The current study suggests that the form of dietary vitamin $\mathrm{D}$ supplementation $\left(25(\mathrm{OH}) \mathrm{D}_{3}\right.$ or vitamin $\left.\mathrm{D}_{3}\right)$ did not impact milk vitamin $\mathrm{D}$ concentrations since feeding either 2,000 IU of vitamin $\mathrm{D}_{3}$ or $25(\mathrm{OH}) \mathrm{D}_{3}$ resulted in similar piglet serum $25(\mathrm{OH}) \mathrm{D}_{3}$ concentrations at weaning. Witschi et al. (2011) observed increased serum $25(\mathrm{OH}) \mathrm{D}_{3}$ of piglets from sows fed $25(\mathrm{OH}) \mathrm{D}_{3}$ compared with piglets from sows fed vitamin $\mathrm{D}_{3}$ at the same IU equivalency, 
but their results were confounded with creep feed diets that were provided to suckling pigs starting on the third week of lactation, with pigs being weaned at $5 \mathrm{wk}$ of age. The data herein suggest that the level of maternal dietary vitamin D supplementation is more impactful on milk transfer of the vitamin rather than form (either vitamin $\mathrm{D}_{3}$ or $25(\mathrm{OH}) \mathrm{D}_{3}$ ) of the vitamin when pigs are weaned at approximately $21 \mathrm{~d}$ of age and creep feed is not provided prior to weaning.

The majority of piglet serum vitamin $\mathrm{D}_{3}$ samples were below the laboratory detectable limit of $1.00 \mathrm{ng} / \mathrm{mL}$, which was expected because of the quick clearance of vitamin $\mathrm{D}_{3}$ from circulation. Samples below that threshold (144 out of 192) were not included in the statistical analysis; therefore, the results were summarized as the percentage of samples that were above the lowest detectable limit, and then the average serum concentration of the detectable samples was calculated. Only $54.2 \%$ of pigs from sows fed 9,600 IU of vitamin $\mathrm{D}_{3} / \mathrm{kg}$ exhibited serum vitamin $\mathrm{D}_{3}$ concentrations above the detectable limit, with mean serum concentrations of $1.7 \mathrm{ng} / \mathrm{mL}$. Increasing maternal dietary vitamin $\mathrm{D}_{3}$ increased (quadratic, $P=0.001$ ) the percentage of pigs with serum vitamin $\mathrm{D}_{3}$ concentrations above the detectable limit, and greater percentages of pigs from sows fed 2,000 or 9,600 IU of vitamin $\mathrm{D}_{3} / \mathrm{kg}$ had serum vitamin $\mathrm{D}_{3}$ concentrations $(P<0.001)$ above the detectable limit compared with pigs from sows fed $50 \mu \mathrm{g}$ of $25(\mathrm{OH}) \mathrm{D}_{3} / \mathrm{kg}$.

Piglet serum $\alpha$-tocopherol was similar after birth and at weaning regardless of vitamin $\mathrm{D}$ maternal treatment. A tendency $(P=0.065)$ for a treatment $\times$ day interaction for piglet serum retinol was observed because at birth piglet serum retinol was reduced (quadratic, $P=$ 0.031 ) with increasing maternal vitamin $D_{3}$, and piglets from sows fed diets with a medium level of vitamin $\mathrm{D}_{3}$ had lower $(P=0.038)$ serum retinol compared with piglets from sows fed $25(\mathrm{OH}) \mathrm{D}_{3}$; however, by weaning, serum retinol was similar regardless of maternal vitamin $\mathrm{D}$ treatment. These differences in serum retinol in piglets at birth were unexpected and may be due to piglets from sows fed the medium level of vitamin $D_{3}$ having lower serum retinol in later gestation, although it is unclear why this would have occurred.

Percentage bone ash for second ribs and femurs from pigs euthanized after birth was similar regardless of vitamin D treatment. Similarly, Flohr et al. (2014) observed no impact of increasing maternal vitamin $\mathrm{D}_{3}$ concentration (1,500 to $6,000 \mathrm{IU} / \mathrm{kg}$ of diet) on the bone ash percentage of neonates when maternal vitamin $\mathrm{D}_{3}$ was above the animal's requirement. Alternatively, Rortvedt and Crenshaw (2012) clearly demonstrated the impact of maternal vitamin D deficiency on subsequent pig kyphosis; however, visual impacts of maternal deficiency were not observed until after weaning. A previous study with rat (Johnson et al., 1996) fetuses detected vitamin D receptor within fetal tissues prior to ossification, alluding to the functional role of vitamin D in the proliferation and differentiation of chondrocytes in skeletal tissue. In the current study, the maternal vitamin D supplementation concentrations were well above those needed to induce a vitamin $\mathrm{D}$ deficiency in sows.

\section{Neonatal Muscle Characteristics}

Previous research by Hines et al. (2013) concluded that replacing $80 \%(2,000 \mathrm{IU}$ of the total $2,500 \mathrm{IU} / \mathrm{kg}$ of diet) of the vitamin $\mathrm{D}_{3}$ supplemented to gestating gilts with $25(\mathrm{OH}) \mathrm{D}_{3}$ increased the maternal vitamin $\mathrm{D}$ status and in turn altered fetal muscle development. The authors observed an increase in the number of skeletal muscle fibers and Pax7 (satellite cells) + myoblasts in the LM of fetuses collected on d 90 of gestation. Additionally, after isolating and culturing myoblasts from the semitendinosus muscle, the satellite cells from fetuses of gilts supplemented $25(\mathrm{OH}) \mathrm{D}_{3}$ had a higher proportion of cells in the proliferation stage 96 $\mathrm{h}$ postplating, which suggests increased hyperplasia of myoblasts. These conclusions suggest that vitamin D status of the dam can alter fetal skeletal muscle development with positive changes resulting from the use of $25(\mathrm{OH}) \mathrm{D}_{3}$ compared with vitamin $\mathrm{D}_{3}$ itself. Previous work in poultry has elicited similar results (Giuliani and Boland, 1984) and has shown that exogenous addition of $1,25-\mathrm{OH} 2-\mathrm{D}_{3}$ to primary cultures of embryonic chick myoblasts stimulated proliferation and differentiation. In the current study, a subsample of pigs was euthanized to obtain longissimus thoracis (LT) and semitendinosus (ST) whole-muscle cross sections for immunohistochemistry to characterize potential development differences among maternal vitamin D treatments. Although Pax 7+ myoblasts within muscles were not quantified in the current study, we hypothesized that neonatal muscle samples of pigs born from sows fed the $25(\mathrm{OH}) \mathrm{D}_{3}$ compared with those from sows fed 800 or 2,000 IU of vitamin $\mathrm{D}_{3} / \mathrm{kg}$ would have an increased number of muscle fibers. Additionally, if vitamin D status were the reason for the change in fetal muscle fiber numbers, then muscle samples from pigs born from sows fed 9,600 IU of vitamin $\mathrm{D}_{3} / \mathrm{kg}$ should be similar to the fiber numbers from muscles of pigs born from sows fed $50 \mu \mathrm{g}$ of $25(\mathrm{OH}) \mathrm{D}_{3} / \mathrm{kg}$ of diet.

Results from the current study showed that wholemuscle areas of the LT and ST were similar regardless of maternal vitamin D treatment (Table 8). Maternal vitamin D treatment did not influence ST average muscle fiber cross-sectional area (CSA), but LT average muscle fiber CSA tended $(P=0.057)$ to be greater for piglets from sows fed $25(\mathrm{OH}) \mathrm{D}_{3}$ compared with piglets 
from sows fed 9,600 IU of vitamin $\mathrm{D}_{3} / \mathrm{kg}$. Average primary muscle fiber CSA was similar for the LT regardless of maternal vitamin D treatment; however, primary muscle fiber CSA for the ST was greater $(P=0.031)$ for piglets from sows fed $25(\mathrm{OH}) \mathrm{D}_{3}$ compared with piglets from sows fed 9,600 IU of vitamin $\mathrm{D}_{3} / \mathrm{kg}$. Secondary muscle fiber CSA for the ST was not influenced by maternal vitamin D treatments, but LT secondary muscle fiber CSA tended to be greater $(P=0.070)$ for piglets from sows fed $25(\mathrm{OH}) \mathrm{D}_{3}$ compared with piglets from sows fed 9,600 IU of vitamin $\mathrm{D}_{3} / \mathrm{kg}$. Total fiber number, primary fiber number, and secondary fiber number for LT and ST muscles were not influenced by maternal dietary vitamin $\mathrm{D}$ treatment. The LT secondary to primary fiber ratio was lower $(P=0.035)$ for piglets from sows fed $25(\mathrm{OH}) \mathrm{D}_{3}$ compared with piglets from sows fed $9,600 \mathrm{IU}$ of vitamin $\mathrm{D}_{3} / \mathrm{kg}$; however, maternal dietary vitamin D treatment did not influence ST secondary to primary muscle fiber ratio.

The results herein contradict those previously reported by Hines et al. (2013) in the sense that total muscle fiber numbers were not different among maternal vitamin D treatments. The current data suggest little to no impact of the maternal vitamin $\mathrm{D}$ treatments on neonatal muscle characteristics except for increases in the hypertrophic growth of the primary muscle fibers of the ST and the secondary muscle fibers of the LT for pigs from sows fed $25(\mathrm{OH}) \mathrm{D}_{3}$ compared to pigs from sows fed 9,600 IU of vitamin $\mathrm{D}_{3} / \mathrm{kg}$. More research is needed to help elucidate whether there are distinct impacts of maternal vitamin $\mathrm{D}$ supplementation from vitamin $\mathrm{D}_{3}$ or $25(\mathrm{OH}) \mathrm{D}_{3}$ on fetal muscle development and what levels of the vitamin are optimal.

\section{Conclusion}

Overall, the results of this study indicate that supplementing increasing levels of maternal vitamin $\mathrm{D}_{3}$ to sows can increase sow and piglet serum $25(\mathrm{OH}) \mathrm{D}_{3}$. Additionally, when supplementing $25(\mathrm{OH}) \mathrm{D}_{3}$ and vita$\min \mathrm{D}_{3}$ at the same IU equivalency, serum $25(\mathrm{OH}) \mathrm{D}_{3}$ of sows and piglets at birth will be increased for sows fed $25(\mathrm{OH}) \mathrm{D}_{3}$. It appears that maternal dietary vitamin $\mathrm{D}$ level impacted weaned pig serum $25(\mathrm{OH}) \mathrm{D}_{3}$ more so than the form (vitamin $\mathrm{D}_{3}$ or $25(\mathrm{OH}) \mathrm{D}_{3}$ ) of vitamin $\mathrm{D}$. This is likely due to increased vitamin $\mathrm{D}$ in milk as a result of an increased level of the maternal dietary supplementation rather than the vitamin $\mathrm{D}$ form. Maternal vitamin $\mathrm{D}$ treatment (above the basal requirement) had minimal impact on sow performance, neonatal percentage bone ash, or neonatal muscle development characteristics.

\section{LITERATURE CITED}

AAFCO. 2015. 2015 Official publication. Assoc. Am. Feed Control Off., Champaign, IL.

Abawi, F. G., and T. W. Sullivan. 1989. Interactions of vitamins A, $D_{3}$, E, and K in the diet of broiler chicks. Poult. Sci. 68:1490-1498. doi: $10.3382 /$ ps. 0681490

Bar, A., M. Sharvit, D. Noff, S. Edelstein, and S. Hurwitz. 1980. Absorption and excretion of cholecalciferol and of 25-hydroxycholecalciferol and metabolites in birds. J. Nutr. 110:1930-1934.

Bouillon, R., H. Van Baelen, B. Keng Tan, and P. De Moor. 1980. The isolation and characterization of the 25-hydroxyvitamin D-binding protein form chick serum. J. Biochem. 255:1092510930.

Clements, M. R., and D. R. Fraser. 1988. Vitamin D supply to the rat fetus and neonate. J. Clin. Invest. 81:1768-1773. doi:10.1172/ JCI113518

Clinton, S. K. 2013. Vitamin D. In: M. H. Stipanuk and M. A. Caudill, editors, Biochemical, physiological, and molecular aspects of human nutrition. 3rd ed. Elsevier Saunders, St. Louis, MO. p. 703-717.

Coffey, J. D., E. A. Hines, J. D. Starkey, C. W. Starkey, and T. K. Chung. 2012. Feeding 25-hydroxycholecalciferol improves gilt reproductive performance and fetal vitamin D status. J. Anim. Sci. 90:3783-3788. doi:10.2527/jas.2011-5023

Endo, I., D. Inoue, T. Mitsui, Y. Umaki, M. Akaike, T. Yoshizawa, S. Kato, and T. Matsumoto. 2003. Deletion of vitamin D receptor gene in mice results in abnormal skeletal muscle development with deregulated expression of myoregulatory transcription factors. Endocrinology 144:5138-5144. doi:10.1210/en.2003-0502

Feedstuffs. 2010. Kent feeds recalls certain swine feeds. http://fdsmagissues.feedstuffs.com/fds/PastIssues/FDS8225/fds02_8225. pdf. (Accessed 4 April 2011.)

Flohr, J. R., M. D. Tokach, S. S. Dritz, J. M. DeRouchey, R. D. Goodband, J. L. Nelssen, and J. R. Bergstrom. 2014. An evaluation of the effects of added vitamin $\mathrm{D}_{3}$ in maternal diets on sow and pig performance. J. Anim. Sci. 92:594-603. doi:10.2527/ jas.2013-6792

Giuliani, D. L., and R. L. Boland. 1984. Effects of vitamin $\mathrm{D}_{3}$ metabolites on calcium fluxes in intact chicken skeletal muscle and myoblasts cultured in vitro. Calcif. Tissue Int. 36:200-205. doi:10.1007/BF02405318

Goff, J. P., R. L. Horst, and E. T. Littledike. 1984. Effect of sow vitamin D status at parturition on the vitamin D status of neonatal piglet. J. Nutr. 114:163-169.

Goncalves, A., S. Roi, M. Nowicke, A. Dhaussy, A. Huertas, M. J. Amiot, and E. Reboul. 2015. Fat-soluble vitamin intestinal absorption: Absorption sites in the intestine and interactions for absorption. Food Chem. 172:155-160. doi:10.1016/j.foodchem.2014.09.021

Haddad, J. G., Jr., V. Boisseau, and L. V. Avioli. 1971. Placental transfer of vitamin $\mathrm{D}_{3}$ and 25-hydroxycholecalciferol in the rat. J. Lab. Clin. Med. 77:908-915.

Hines, E. A., J. D. Coffey, C. W. Starkey, T. K. Chung, and J. D. Starkey. 2013. Improvement of maternal vitamin D status with 25-hydroxycholecalciferol positively impacts porcine fetal skeletal muscle development and myoblast activity. J. Anim. Sci. 91:4116-4122. doi:10.2527/jas.2013-6565.

Hollis, B. P., J. Q. Kamerud, S. R. Selvaag, J. D. Lorenz, and J. L. Napoli. 1993. Determination of vitamin D status by radioimmunoassay with an ${ }^{125}$ I-labeled tracer. Clin. Chem. 39:529-533.

Hollis, B. W., and C. L. Wagner. 2004. Assessment of dietary vitamin D requirements during pregnancy and lactation. Am. J. Clin. Nutr. 79:717-726. 
Institute of Medicine. 2011. Dietary reference intakes for calcium and vitamin D. Natl. Acad. Press, Washington, DC.

Johnson, J.A., J. P. Grande, P. C. Roche, and R. Kumar. 1996. Ontogeny of the 1,25-dihydroxyvitamin $\mathrm{D}_{3}$ receptor in fetal rat bone. J. Bone Miner. Res. 11:56-61. doi:10.1002/jbmr.5650110109

Kass, R. E., and A. E. Raftery. 1995. Bayes factors. J. Am. Stat. Assoc. 90:773-795. doi:10.1080/01621459.1995.10476572

Lauridsen, C., U. Halekoh, T. Larsen, and S. K. Jensen. 2010. Reproductive performance and bone status markers of gilts and lactating sows supplemented with two different forms of vitamin D. J. Anim. Sci. 88:202-213. doi:10.2527/jas.2009-1976

Norman, A. W., and R. Bouillon. 2010. Vitamin D nutritional policy needs a vision for the future. Exp. Biol. Med. 235:1034-1045. doi:10.1258/ebm.2010.010014

NRC. 2012. Nutrient requirements of swine. 11th rev. ed. Natl. Acad. Press, Washington, DC.

Paulk, C. B., M. D. Tokach, J. L. Nelssen, D. D. Burnett, M. A. Vaughn, K. J. Phelps, S. S. Dritz, J. M. DeRouchey, R. D. Goodband, J. C. Woodworth, T. A. Houser, K. D. Haydon, and J. M. Gonzalez. 2014. Effects of dietary zinc and ractopamine hydrochloride on pork chop muscle fiber type distribution, tenderness, and color characteristics. J. Anim. Sci. 92:2325-2335. doi:10.2527/ jas.2013-7318

Payne, J. M., and R. Manston. 1967. The safety of massive doses of vitamin $\mathrm{D}_{3}$ in the prevention of milk fever. Vet. Rec. 81:214-216. doi:10.1136/vr.81.9.214
Priego Capote, F., J. R. Jimenez, J. M. Granados, and M. D. de Castro. 2007. Identification and determination of fat-soluble vitamins and metabolites in human serum by liquid chromatography/triple quadrupole mass spectrometry with multiple reaction monitoring. Rapid Commun. Mass Spectrom. 21(11):1745-1754. doi: $10.1002 / \mathrm{rcm} .3014$

Rortvedt, L. A., and T. D. Crenshaw. 2012. Expression of kyphosis in young pigs is induced by a reduction of supplemental vitamin $\mathrm{D}$ in maternal diets and vitamin $\mathrm{D}, \mathrm{Ca}$, and $\mathrm{P}$ concentrations in nursery diets. J. Anim. Sci. 90(13):4905-4915. doi:10.2527/ jas.2012-5173

Schadt, H. S., R. Gössl, N. Seibel, and C. P. Aebischer. 2012. Quantification of vitamin $\mathrm{D}_{3}$ in feed, food, and pharmaceuticals using high-performance liquid chromatography/tandem mass spectrometry. J. AOAC Int. 95:1487-1494. doi:10.5740/jaoacint.11-512

Town, S. C., C. T. Putman, N. J. Turchinsky, W. T. Dixon, and G. R. Foxcroft. 2004. Number of conceptuses in utero affects porcine fetal muscle development. Reproduction 128:443-454. doi:10.1530/rep.1.00069

Weber, G. M., A.-K. M. Witschi, C. Wenk, and H. Martens. 2014. Triennial Growth Symposium-Effects of dietary 25-hydroxycholecalciferol and cholecalciferol on blood vitamin D and mineral status, bone turnover, milk composition, and reproductive performance of sows. J. Anim. Sci. 92:899-909. doi:10.2527/ jas.2013-7209

Witschi, A.-K. M., A. Liesegang, S. Gebert, G. M. Weber, and C. Wenk. 2011. Effect of source and quantity of dietary vitamin D in maternal and creep diets on bone metabolism and growth in piglets. J. Anim. Sci. 89:1844-1852. doi:10.2527/jas.2010-3787 